\title{
Antecedences of Employees' Creativity: Evidence From IT, Educational and Advertisement Sectors of Pakistan
}

\author{
Abdullah Shahid \\ Karachi University Business School, University of Karachi, Pakistan \\ E-mail: abdullahshahid302@hotmail.com \\ Dr. Danish Ahmed Siddiqui \\ Karachi University Business School, University of Karachi, Pakistan \\ E-mail: daanish79@hotmail.com
}

Received: April 1, 2020 Accepted: April 25, 2020 Published: May 1, 2020

doi: 10.5296/hrr.v4i1.16780 URL: https://doi.org/10.5296/hrr.v4i1.16780

\begin{abstract}
This study aims to propose elaborative theoretical framework to assess factors that influences creativity. We combine (Teresa et al., 1996; Jothi \& Hin, 2015; Lin \& Liu, 2012; Yeh \& Huan, 2017) models featuring work and its environmental related factors into one holistic framework to assess the antecedents and consequence of creativity. We propose two level mediation to assess the effect of environmental variables on innovation and motivations through creativity as well as Job Stressors. Environmental factors included Leaders Behavior, Freedom, Resources, Social Support, Workload, Perceived Organizational Support, Person job fit, and Challenging work. Perceived Organizational Support was further affected by Organizational impediments, Supervisory encouragement, and Work group supports. These factors influences Job Stressors that include Challenge and Hindrance stressors, and work pressures in environment. These stressors further affect creativity as proposed by Zhang \& Wee (2018). We also categorize creativity into Quantity and Quality as per Yeh \& Huan, (2017). Empirical validity was established by conducting a survey of employees in high creativity sectors like IT, Educational and Advertisement. Result shows that among work and environmental factors, only Leaders Behavior, Perceived Organizational Support, and Challenging work significantly affect job stressors. On the contrary, job stressors significantly affect both Quantity and Quality of creativity. However, subsequent effect of creativity on innovation and motivation could not be established.
\end{abstract}




\section{$\triangle$ Macrothink}

Keywords: Freedom, Resources, Social Support, Workload, Person job fit, Challenging work, Leaders Behavior, Perceived Organizational Support, Challenging work, Creativity

\section{Introduction}

\subsection{Background to the Study}

Creativity is prominently well known and celebrated for generation of novel and useful ideas for any organization that works for satisfying peoples' evolving needs, for that organization are in need to form a trustworthiness among the employees and indulge them decision making processes, appreciating the workers and establishing appropriate norms that employees deserve, in such environment one can see creativity grow and eventually obtain benefits (Ohly, 2018). However many organizational behavior researchers are putting great attention to workload because it is effecting employee psychological health and wellbeing and also effecting organizational performance (Jex et al., 2001). Most organizational behavior researcher putting great attention to workload because it effecting employee psychological health and wellbeing and also effecting organizational performance (Jex, Bliese, Buzzell, \& Primeau, 2001)

In their continuous effort to discover the new paradigms, organization are trying to establish individual creativity (Gu et al., 2013). According to Davis et al., (2010) the creativity of any individual can be improved and also it can be taught. However employees are the valuable assets of any organization when they are inclined towards introducing new ideas by using their ability of creative performance Collins and Cooke (2013).

According to one research, if you have employees in your organization who implement new ideas and policy by their creative capabilities, so they will be your valuable asset (Tierney et al., 1999). Creativity can be described as producing new ideas and make different point of view. Creativity is about to take an existing problem and solve it, in a new way(Jothi \& Hin, 2015). There is no limitation on individual's creativity it can be taught and improve (Landau, 1937)

In every company some activities are formal and some are informal activities if we talk about the research perspectives so we can say that both activities are create the problem for employees creativity (Mayer \& Solga, 2008). There is a mediation effect of mindfulness over the creativity of employee and the creativity further mediates results of creative process engagement on the performance of employees. Therefore mindfulness of a person plays a role to stick to and eventually increases the understanding with lesser confusion while it helps in fostering the focus and eliminate the disconnection of employee understanding (Ngo et al., 2020). Many researches have been accounted for leadership styles and their impact over the creativity of employees, for that Cai et al., (2019) showed that entrepreneurial leadership have a positive relation with employee creativity whereby it helps workplace endeavors to facilitate employees to achieve more creative ideas through mediating role of self-efficacy and team efficacy. But a transactional leadership style has suppressed the ways of creativity for employees in several banks of Pakistan(S. Rahman, 2017). Therefore, in comparison of transformation leadership and transactional leadership, the later has come up as destroyer for the employees' creativity and learning orientation due to continuous dissection. Furthermore transactional leadership is not found to be apt for generation of creativity among the 
employees. However a transformational leader is advocated as the entertainer for creativity and has grown its favorability over the time (Ebrahimi et al., 2017).

Our study is accounted to analyze the consequences of workload over innovative creativity of the employees in Pakistan. However the studies on creativity have been commenced since mid- $20^{\text {th }}$ century and has played an integral role in education and by generating a great wealth of knowledge through empirical and theoretical views (Hernández-Torrano \& Ibrayeva, 2020). On the other hand the information technology and advertising agency are more inclined toward innovation to produce and develop appealing and also trendy content and products to attract their customers and stakeholders and obtain benefits from their new development. To achieve the creative content and innovation organizations tend to put unusual workload and pressure on their employees, for that, is the same reason for which we are analyzing the logical pre requisites for the creativity. Such research is expected to address the right direction to the industry to attain the creativity and innovation in the employees and simultaneously keeping them productive as well.

\subsection{Problem Statement}

Sometimes people try to meet their long-term plans with very narrow minded approach which is generally perceptible for them. It can be observed that, through modifying our perceptions and evaluating our needs, based on that, when we reframe the way of observing our problems and meet circumstances with open minded approach we can have the ability to solve complex problems more efficiently (Kumar, 2017). However, there are a number of factors that have the power to damage the creativity of employees like if organization follow the culture that discourages the new idea that comes from the employees so it will decrease the creativity level of employee, organizational politics are the one reason behind diminishing the employees' creativity, bad attitude by the senior management towards employees and also offensive supervision by the management is the reason to diminishing of the employee creativity because of these type of cultures of the organizations and bad attitudes by the senior management demotivates employees towards their job (Teresa M. Amabile et al., 1996). however according to a study an utter understanding can be established through creative attitudes that emerge within the firms and they append to enrich the literature available for creativity through defining the contemporary part that sharing of knowledge plays. Some organizational climate factors such as, perceived organizational politics and the quality of relationship are one of the reason that helps creativity to grow within the organization through usefulness of combined and individual influences in the organization ( $Z$. Rahman, 2016).

Workplace which is alternative to release the tension in their mind and negative thinking produce a harmful for the employee creativity (Cowie et al., 2002).

In stressful environment it is somehow hard for Creativity to survive, while it becomes confusing and further an increased workload pressure density tensions for employees which then compels individuals to imitate responsive actions therefore to address these issue a leader should indulge as role model to strengthen the creative self-efficacy of the employees (Shao et al., 2019a). Although cultural differences among the employs effect their creativity in manifold therefore Yong et al. (2020) are of opinion that culture has multidimensional nature therefore it becomes difficult for the person to understand behavior of employees and 
further suggests that to understand cultural impact on creativity one needs to study holistically rather in isolation.

This paper is destined to achieve solutions to employees' problems which derive their motivation to creativity lowest. The redressal of employee grievances has become so important in Pakistan that in different sectors of Pakistan employees tend to achieve growth by utilizing their creativity and skills knowledge sharing rather than seniority promotions.

\subsection{Gap Analysis}

Amabile et al., (1996) Assessed the work environment for creativity. They identified key environmental conditions that nurture creativity i.e. challenging work, organizational encouragement, work group support, freedom, absence of organizational impediments, supervisory encouragement, sufficient resources, and workload pressure. (Glynn, 1996) explored individual creativity and organizational innovation by using a host of individual (motivation, personality, expectations), job (novelty, challenge), and organizational (structure, culture, technology) variables. Jothi \& Hin, (2015) examined the effect of workload pressure, person-job fit and moderating effect of innovation trust on creativity among educators of private higher education institutions in Malaysia. Lin \& Liu, (2012) highlighted the effect of organizational creativity climate on perceived innovation. It indicated that 27 percent variance of perceived innovation could potentially be explained by creativity climate. Yeh \& Huan, (2017) explored the factors that influence the creativity of restaurant employees. They hypothesised that social support within an organization, resources, freedom, and regulations, strongly impact the creativity of employees.

Meanwhile, with respect to Pakistan, Rabbani \& Sarmad (2018) explored the role of creative self-efficacy between climate for creativity dimensions and creativity among $R \& D$ employees of IT industry of Pakistan. Similarly Usman \& Xiao, (2017) have explored the role ambiguity as an antecedent of the creativity of employees.

To sum up, most of the studies focused on the antecedents of creativity, highlighting job, human, and organisational factors. However, they fell short in explaining how these factors effected it. Few studies also focused the onward effect of creativity on variables like motivation and innovation, but no such study attempted to tackle both of these issues in a single structural framework. For this, we combine (Teresa M. Amabile et al., 1996; Jothi \& Hin, 2015; Lin \& Liu, 2012; Yeh \& Huan, 2017) models featuring work and its environmental related factors into one holistic framework to assess the antecedents and consequence of creativity. We propose two level mediation to assess the effect of environmental variables on innovation and motivations through creativity as well as Job Stressors.

Moreover, no such work was carried out on Pakistan. Furthermore, previous researches were restricted to specific industry and business sector but in this study empirical validity was established by conducting a survey of employees in high creativity sectors like IT, Educational and Advertisement.

\subsection{Research Objectives}

This study aims to propose elaborative theoretical framework to assess factors that influences creativity. We combine (Teresa M. Amabile et al., 1996; Jothi \& Hin, 2015; Lin \& Liu, 2012; 


\section{Ml Macrothink}

Yeh \& Huan, 2017) models featuring work and its environmental related factors into one holistic framework to assess the antecedents of creativity. These factors include Leaders Behavior, Freedom, Resources, Social Support, Workload, Perceived Organizational Support, Person job fit, and Challenging work. Perceived Organizational Support was further classified into Organizational impediments, Supervisory encouragement, and Work group supports. We also categorize creativity into Quantity and Quality as per Yeh \& Huan, (2017). We further proposed a mediation role of Job Stressors that include Challenge and Hindrance stressors, and work pressures in environment and creativity as proposed by Zhang \& Wee (2018). Although this research is conducted within the Pakistani sector and was conducted on Information technology industry, Advertising Agencies and Educational Sector.

\subsection{Research Question}

- How workload effects the creative performance of employees in the IT, Education and Advertising Industry of Pakistan?

- How does Perceived organizational Support effects the Challenge Stressor in IT, Education and Advertising Industry of Pakistan?

- How does Perceived organizational Support effects the Hindrance Stressors in IT, Education and Advertising Industry of Pakistan?

- What is the impact of Creative performance on the Motivation in IT, Education and Advertising Industry of Pakistan?

- What is the impact of Creative performance on the Innovation in IT, Education and Advertising Industry of Pakistan?

\subsection{Significance}

In turn, we propose that the translation of work overload into reduced creative behavior might not be an automatic process but rather could be countered to the extent that employees have access to resources that spur their ability or desire to develop new ideas from which their organization can benefita (Bakker \& Xanthopoulou, 2013) Thus, we consider how resource access may be instrumental for preventing employees from responding negatively to excessive workloads, in the form of reduced creativity. This issue is especially pertinent for organizations that function in competitive external environments that require them to impose significant time pressures on their employees (Altaf \& Awan, 2011; Avery et al., 2010). Moreover, this study will indicate that employees who feel creative about their work may be better prepared to cope with excessive workloads. Creativity and Passion for work thus provides an important means that organizations eager to stimulate creativity can use to mitigate the problems of excessive workloads. Creative people tend to be more involved in their work, which gives them a greater ability and motivation to deal with unrealistic timelines and cope with the associated stress, and these features ultimately can be beneficial for increasing the organization's creative profile. To increase the likelihood that current and future employees exhibit a strong passion for work, organizations could demonstrate how that creativity can help resolve a wide range of organizational problems, particularly those that employees are most interested in at a personal level.

Most important significance of this study is that we propose a frame work which include different dimensions of workload and creativity, namely (organizational impediments, 
supervisor encouragement, work group support, perceived organizational support, challenge stressor, hindrance stressor, work pressure, social support, resources adequacy, freedom, challenge, work load, person-job, leaders behavior, quality of creativity, quantity of creativity, motivation and innovation). These dimensions will benefit the organization to tackle the impact of workload on creativity.

\section{Literature Review}

\subsection{Employee Creativity}

Creativity is the process of converting imaginative idea into realistic things and creative employees in organization can bring the more productivity than non-creative employee's. Baer (2012) examined that employee creativity can facilitate the organization to find the opportunities and quick respond to growth and economic situation.

Shalley \& Gilson (2004) contended that manager is one who encourage employee and provide resources to improve the creativity of employee like they said that organizations support their employee to improve creativity. But there is difference in opinion that organizational support effect employee creativity.

Kim et al., (2010) showed that supervision by managers and support from organizations can improve creativity of employee. Bammens (2013) suggested that employee feel higher motivation to keep in creative process when they perceive support from organization. Khazanchi \& Masterson, (2011) showed that there is no direct relation between organizational support and employee creativity. Tang and Chang, (2010) demonstrates that perceived role ambiguity has direct negative impact on creativity of employee, if the organization will not define the role of the employees therefore it will not decrease the creative of employee.

Glazer \& Beehr, (2005) examined that the relation between role conflict and employee creativity is relevant and employee creativity is essential to the growth and success of the organization, and also the numbers of employees is suffering from the role stress. Tang \& Chang, (2010) indicate that employee creativity is effected by role conflict in a positive waythat means employee creativity will increase when employee suffering by role conflict. Therefore, employee creativity will affect by the role conflict and role ambiguity either in a positive or negative way.

Zhou et al., (2012) shows that specific working condition like challenging work and high job demand will enhance the capability of employee's creativity because in a tough working conditions employees sees a new ways to do the work. De Jonge \& Dormann, (2003) contended that the particular complex working problems are considered valuable to commence employee's creativity but only in that condition where employees have satisfactory cognitive resources.

Coelho \& Augusto (2010) contended that in particular situation where employee has direct relation with their customer and they had to fulfill their demand and they had required to handle the multiple customer at work, employees need to display their creativity in that way to bring out their daily practices, this creativity is named as "little-c" (everyday) creativity than eminent creativity. Version (2004) identified the need of creative employees in service oriented organization, since service employees need to fulfill the customer need by the 
constructive ideas and the creativity of employees with the solution of customer's problem have the potential to effect the customer satisfaction.

Hur et al. (2016) showed that those service oriented employee who experienced incivility on the workplace have the low level of creativity because incivility have the negative impact on creativity of service oriented employees through emotional exhaustion and it reduces the level of intrinsic motivation of employees

Carmeli et al., (2015)contended that the social interaction and relations with other members of the organization have the positive effect on the creativity of employee, they also analyze the group and individual's creativity and social interaction has the positive effect on them therefore social engagement at workplace have importance in the organization for enhance the employee creativity.

Dul \& Ceylan, (2010) shows that the working environment at the workplace can enhance the creativity of the employee and there are tools and solution available to appreciate the work environment that supporting creativity. (Mumford,et al., (2002) contended that there is strong relationship between effective illness and higher level of creative achievement, but he noted that this relationship applies on artist, not scientist creativity. George \& Zhou (2002) suggested the mood input model which proposed that when employee experience positive affect at workplace and also aware that affective state, this is a situation

(Bammens et al., 2013) suggested that employee feel higher motivation to keep in creative process when they perceive support from organization.

(Khazanchi \& Masterson, 2011) showed that there is no direct relation between organizational support and employee creativity.

(Tang \& Chang, 2010) demonstrates that perceived role ambiguity has direct negative impact on creativity of employee, if the organization will not define the role of the employees therefore it will not decrease the creative of employee.

(Mumford et al., 2002) contended that there is strong relationship between effective illness and higher level of creative achievement, but he noted that this relationship applies on artist, not scientist creativity.

(George \& Zhou, 2002) suggested the mood input model which proposed that when employee experience positive affect at workplace and also aware that affective state, this is a situation which calls creativity and they interpret that positive mood as an indicator that they have meet creative goal.

Creativity has been treated with two dimensions of Quality and Quantity (Yeh \& Huan, 2017) however the definition for creativity (McLean, 2005; Ohly, 2018; Yeh \& Huan, 2017) opines that creativity is an approach to the ideas that novel in nature.

\subsection{Workload}

Workload is about to given the unrelated, undefined task to the employees who are not qualified for that job. When there is too much work and you have too short period of time, this is also called workload. Workload is about to having the high amount of work by the organization and the task which has to completed within given period of time and also about that condition in which employees has to done work very fast, these kind of situation at 


\section{MInstitute Macrothink $_{\text {Int }}$}

workplace has linked with decrease the job satisfaction and also it create general psychological problem and create conflict among the work-family life (Byron, 2005)

This perspective has been hold by many prior studies which relating workload with negative employee and organizational outcomes such as absenteeism, low job satisfaction, turnover and decreased work performance (Harvey et al., 2003). Cannon-Bowers \& Salas, (1997) showed that employee work performance have negatively affect by higher level of workload. Glaser (2015) identified that, when workload increase it may detriment effects on performance indirectly in increasing in stress.

El-Shikieri \& Musa, (2012) contended that overload work has the negative and positive stress on employees, when the level of work exceed it put negative effect on employee. Excessive workload is not compulsory for most of the job so that organizations can do a great deal to ensure that employees are assigned workload that is manageable. Workload is associated with several negative outcomes, like employee absenteeism, reducing organizational commitment and reasons to health illness. Bowling research highlight the negative aspect of workload but this study proved that workload also has positive outcomes like it increase creativity of IT sector employees therefore creative employee can boast to the organizational Hon \& Kim (2007) mentioned that occurrence of higher workload may be positively influence individual creativity. Lee et al., (2013) identified factors that will suppress creativity such as extreme deadline, unrealistic expectation and environment distraction that induces pressure of workload.

\section{Theoretical Framework}

\section{Perceived Organizational Support}

Perceived organizational support is taken as a thought that helps to enhance the creativity of employees within the organization. And many scholars have suggested that POS encourages employees to engage in creative environment, however, not consistent in nature, some studies have implied that the nexus between POS and Employees' creativity can be conditional. (L. Zhang et al., 2018). It has been argued that POS helps to fulfill important socioemotional needs for positive self-esteem, approval, and affiliation (Armeli, Eisenberger, Fasolo, \& Lynch, 1998), which leads employees to incorporate organizational membership and role status into their social identity (Rhoades \& Eisenberger, 2002). According to social identity theory, to enhance their self-esteem, individuals would classify themselves and others into different categories to define themselves in given environments, and tend to identify with groups that are perceived positively (Tajfel \& Turner, 1985). In line with this view, Shore and Shore (1995) also argued that the perception of organizational support provides employees with important information about his/her relationship to the workplace. Sluss et al. (2008) also argued that organizational support may affirm the employee's value and informal standing as well as increase the organization's perceived attractiveness and organizational identification.

H4: Perceived Organizational Support have a negative and significant effect on challenge Stressor

H5: Perceived Organizational Support have a negative and significant effect on Hindrance Stressor 


\section{Macrothink}

H6: Perceived Organizational Support have a negative and significant effect on Work Pressure

Organisational factors causing Encouragement of creative ideas appears to operate at three major levels within organizations. These included 1. organizational encouragement, 2. supervisory encouragement and 3 . work group encouragement.

\section{Organizational Impediments}

Organizational impediments can be defined as the overall amount of political struggle between the departments, rigid structures and operating procedures, a strong emphasis on following rules and hierarchy, overcritical supervisors, the presence of devastating competition among employees.

Organizational impediments are hindrance that employees face, however, (Teresa M. Amabile et al., 1996) defines organizational impediments as in an environment where creativity is hindered through different factors of culture such as organization's domestic political problems, unusual criticism over new ideas.

Several aspects are perceived as operating broadly across the organization:

(1) The first is encouragement of risk taking and of idea generation, a valuing of innovation from the highest to the lowest levels of management. Psychological research on creativity has demonstrated that people are more likely to produce unusual, useful ideas if they are given license to do so by the situation or by explicit instructions (Parnes, 1964; Parnes \& Meadow, 1959).

(2) Fair, supportive evaluation of new ideas is the second aspect of organizational encouragement. The expectation of threatening, highly critical evaluation has been shown to undermine creativity in laboratory studies (Amabile, 1979; Amabile, Goldfarb, \& Brackfield, 1990). Moreover, field experiments have demonstrated that supportive, informative evaluation can enhance the intrinsically motivated state that is most conducive to creativity (Deci \& Ryan, 1985).

(3) Although engaging in an activity only to obtain a contracted-for reward can undermine creativity, creativity can be enhanced by expecting a reward that is perceived as a "bonus," a confirmation of one's competence, or a means of enabling one to do better, more interesting work in the future (Amabile et al., 1986).

(4) Finally, collaborative idea flow across an organization and participative management and decision making are important aspects of organizational encouragement. Creativity research has shown that the probability of creative idea generation increases as exposure to other potentially relevant ideas increases (Osborn, 1963; Parnes \& Noller, 1972).

H1: Lack of organizational impediments have a negative and significant effect on Perceived Organizational Support.

\section{Supervisor Encouragement}

Supervisory encouragement often quoted as environmental stimulant to foster the creativity, as Omisore (2014) calls on supervision has the dual effect based on the respective behavior, supervision is one of the reason which makes organizations to achieve the goals as well as supervision has the negative consequences over the productivity of employees. It is likely that 
open supervisory interactions and perceived supervisory support operate on creativity largely through the same mechanisms that are associated with fair, supportive evaluation; under these circumstances, people are less likely to experience the fear of negative criticism that can undermine the intrinsic motivation necessary for creativity (Amabile, 1979).

H2: Supervisor Encouragement have a positive and significant effect on Perceived Organizational Support

Work group Support

Amabile et al. (1996) describes work group support as a group in which there are diversified skilled individuals who are able to communicate well, who are committed to their work, give a competitive challenges to each other's area of work and are open to new ideas. Team member diversity and mutual openness to ideas may operate on creativity by exposing individuals to a greater variety of unusual ideas; such exposure has been demonstrated to positively impact creative thinking (Parnes \& Noller, 1972).

Perceptions of work-group support for creativity are enhanced when group members have diverse backgrounds, are open to new ideas, constructively challenge one another, effectively communicate and provide feedback, successfully manage conflict, trust and help each other, and share a commitment to their work (Teresa M. Amabile et al., 1996; O'Reilly, C. A., \& Tushman, 1997; Taggar, 2002)

Perceived work-group support may also arise when group members like and respect one another (O'Reilly, C. A., \& Tushman, 1997) and when they openly acknowledge the ideas of their colleagues, which tends to expand knowledge sources and encourage original thinking, H3: Work group Support have a positive and significant effect on Perceived Organizational Support.

\section{Social Support}

Amabile et al. (1996) state that encouragement of creativity has three subcategories: organizational encouragement, supervisory encouragement, and work group supports. The idea is that if everyone in a community or an organization works towards creativity, they will gradually construct an atmosphere that encourages creativity (Füller et al., 2011). Certain creative work involves collaborative effort (Adler \& Chen, 2011; Scott \& Bruce, 1994; Taggar, 2002), which is why interaction with and support of co-workers can affect an individual's creativity (Füller et al., 2011). Even with what may seem to be solo-creative work, supportive coworkers may share their knowledge and expertise, provide moral support (Hon, 2011), and increase motivation to commit to creative endeavors (George, 2007).

Based on ideas above, following hypothesis are proposed

H7: Social Support Positively have a negative and significant effect on Challenge Stressor H8: Social Support Positively have a negative and significant effect on Hindrance Stressor H9: Social Support Positively have a negative and significant effect on Work pressure

\section{Resources}

The term resources is used in this study referring specifically to the physical environment such as equipment and facilities that help with an employee's creative tasks. The distinction between social and physical work environment has been used before (e.g., Dul, Ceylan, \& 


\section{$\Lambda$ Macrothink}

Jaspers, 2011). The finding was that they affect both creative performances directly and indirectly (i.e., through moderating individuals' creative personality). The work environment has been defined by a list of elements including furniture, color, lighting, privacy, window view, sound and smell (Dul et al., 2011). An alternative definition is equipment and facilities (Scott \& Bruce, 1994). Work environment has also been considered in terms of cognitive, emotional, and physical resources (Vinarski-Peretz, Binyamin, \& Carmeli, 2011). Other lists includes recipe library, facilities, equipment, disposable time (Scott \& Bruce, 1994), and budget (Adler \& Chen, 2011), for example, for new dish development. Some readers may feel that adequacy is not the right word here. However, it is used in the sense of resources being on a scale from totally inadequate to greatly exceeding minimal needs. In that context, this study postulates following hypothesis

H10: Resources adequacy have a negative and significant effect on Challenge Stressor

H11: Resources adequacy have a negative and significant effect on Hindrance Stressor

H12: Resources adequacy have a negative and significant effect on Work pressure

\section{Freedom}

Amabile et al., (1996) describes Freedom as to decide what work should have the priority for employee himself, as in, resources are the apt facilities available to employees to carry out any task while social support has been described as abutment to creativity and productivity of employees.

One can refer to the contradictory roles of freedom and regulation on employee creativity. It had been suggested that authoritarianism elicits follower's compliance, but may have adverse effects on their affective trust and generate negative emotions that decrease performance (Chen et al., 2014). Zhang et al., (2011) find that authoritarianism elicits follower's compliance, but may have adverse effects on their affective trust and generate negative emotions that decrease performance (Chen, Eberly, Chiang, Farh, \& Cheng, 2014). Zhang, Tsui, and Wang (2011) find that authorarian managers tend to set specific quotas for the employees (Chang et al., 2011). However, simply meeting quotas does not necessarily mean satisfied customers. If customers are not satisfied the firm may be compromised in the long run (Ahearne, Rapp, Hughes, \& Jindal, 2010; Darmon \& Martin, 2011). Stimulating the creative aspect of employee performance has been found to require leeway and autonomy to enable free thinking (Spelthann \& Haunschild, 2011) and individuality (De Stobbeleir et al., 2011). This is especially true in service industries (Spelthann \& Haunschild, 2011), which is the focus of this study. In other words, the literature suggests that meeting a quota for new dish development does not guarantee high customer acceptance of the new dishes. Control has its benefits based on some studies. It is argued that organization exerting more control over the creative process of their employees can facilitate and improve creative performance

(Hernández-Espallardo et al., 2010) It is also noted that a quota-based control system can help in implementing incentive policies that can encourage employees to be more productive (Austin, 2013). Furthermore, it had been suggested that in a collaborative creative task, formal control is essential to coordinate creative efforts (Adler \& Chen, 2011)

H13: Freedom have a negative and significant effect on Challenge Stressor

H14: Freedom have a negative and significant effect on Hindrance Stressor 


\section{MInstitute Macrothin}

H15: Freedom have a negative and significant effect on Work pressure

\section{Person-Job Fit}

P-J fit is defined as the match between the abilities of a person and the demands of a job or the needs/desires of a person and what is provided by a job (Edwards, 1991). In contrast, P-O fit is "the compatibility between people and organizations that occurs when at least one entity provides what the other needs, they share similar fundamental characteristics, or both" (Kristof, 1996, pp. 4-5). Whereas P-J fit is relevant to an individual's compatibility with a specific job, P-O fit pertains to how an individual matches an organization's values, goals, and mission.

Kristof (1996, p. 8) states "it is likely that many job requirements will mirror characteristics of the organization," implying that perceived P-J and P-O fit are likely to be interdependent. However, an employee can possess the skills to be competent in a job, yet not share the organization's values and vice versa. Thus, fit with one aspect of the work environment does not necessarily imply fit with the other. Edwards, (1991) as in (Kristof et al., 2005) have postulated two concepts of Person job fit, Demand - Abilities fit and Supply - Need fit, the earlier concept is about the knowledge skills, and abilities correspond with the required efforts of the job, However, the later concept deals with when desires, needs, and preferences of employees corresponds with the job or activity they have been assigned to do.

H22: Person-Job Fit have a negative and significant effect on challenge Stressor

H23: Person-Job Fit have a negative and significant effect on Hindrance Stressor

H24: Person-Job Fit have a negative and significant effect on Work pressure

\section{Paradoxical Leaders Behavior}

Leaders Behavior can be paradoxical, Y. Zhang et al., (2015) therefore opines that paradoxical leader behavior is contradictory but interrelated to achieve environment for a competent workplace over the time as well as simultaneously.

In dynamic and complex business environments, leaders face contradictory, paradoxical demands and challenges (Smith, Lewis, \& Tushman, 2016; Waldman \& Bowen, 2016; Zhang et al., 2015). Thus, leaders need to meet both structural organizational demands that emphasize order, control, and stability, and follower demands that emphasize freedom, autonomy, and flexibility (Zhang et al., 2015). Similarly, leaders have to manage the paradox between agency and communication inherent to leadership behavior, and between continuity and change inherent to dynamic environments (Waldman \& Bowen, 2016). In contrast to calculated decision making or compromising, paradoxical leaders accept the persistent contradiction between paradoxical challenges and seek to synergize and integrate them within a larger system (Zhang et al., 2015). PLB is defined as leader behaviors that are "contradictory yet interrelated, to meet competing workplace demands simultaneously and over time" (Zhang et al., 2015, p. 538). Zhang and colleagues conceptualized PLB as a behavioral syndrome that consists of five dimensions: (1) combining self-centeredness with other-centeredness, (2) maintaining both distance and closeness, (3) maintaining decision control, while allowing autonomy, (4) enforcing work requirements, while allowing flexibility, and (5) treating subordinates uniformly, while allowing individualization. These authors found that PLB contributed positively to employee proactivity, proficiency, and 
adaptivity, even after accounting for traditional leadership approaches such as transformational and transactional leadership. These five dimensions address different paradoxes, but when considering creativity, the balance between control and autonomy and between structure and flexibility are most relevant (Smith \& Lewis, 2011).

By emphasizing high work requirements and maintaining decision control, paradoxical leaders create a structured, bounded work environment. This helps employees understand work goals, norms and constraints, which is beneficial for achieving useful, practical outcomes at work. Simultaneously, paradoxical leaders construct an autonomous work environment by granting autonomy and flexibility. This supports employees in experimenting with original solutions (Zacher, Robinson, \& Rosing, 2014), enhances intrinsic motivation (Ryan \& Deci, 2000), and encourages creative behavior (Liu, Chen, \& Yao, 2011), which promotes the attainment of novel ideas. This aligns with the ambidexterity literature, which suggests that leaders can support innovation by showing both opening behaviors that encourage exploration and closing behaviors that focus on exploitation (Zacher et al., 2014). Because PLB creates a supportive environment to manage tensions in creativity, employees can gain successful experiences of producing creative outcomes, which strengthens their CSE.

H25: Leaders Behavior have a negative and significant effect on Challenge Stressor

H26: Leaders Behavior have a negative and significant effect on Hindrance Stressor

H27: Leaders Behavior have a negative and significant effect on Work pressure

\section{Workload}

Workload pressure is defined as the extent to which individuals are required to work fast and have too much work to do (Bakker, Evangelia, \& Verbeke, 2004; Voydanoff, 2005). It concerns how much work one has to do in a certain period of time, covering both the quantity and pace of work, and is therefore closely related to time pressure. Interestingly, the effects of workload and time pressure on creativity are inconsistent. Some studies suggest a negative association between workload pressure and creativity (e.g., Amabile et al., 1996), whereas others show a positive relationship (e.g., Janssen, 2000). Similarly, Andrews and Smith (1996) found that time pressure has a negative effect on creativity, while Baer and Oldham (2006) found a curvilinear relationship, and Mehta and Zhu (2016) even found a positive association between time pressure and creativity. When workload pressure is high, the time and energy resources for addressing different goals declines, and employees will experience tensions between competing demands and activities (e.g., Moeini et al., 2008).

H19: Work load have a positive and significant effect on Challenge Stressor

H20: Work load have a positive and significant effect on Hindrance Stressor

H21: Work load have a positive and significant effect on Work pressure

\section{Challenge}

Challenging work is a thought to work hard and put more efforts in challenging job and essential projects (Teresa M. Amabile et al., 1996)

H16: Challenge work have a positive and significant effect on Challenge Stressor

H17: Challenge work have a positive and significant effect on Hindrance Stressor 
H18: Challenge work have a positive and significant effect on Work pressure

\section{Job Stressor}

According to Lazarus (1966), stress occurs when an individual perceives that the demands of an external situation are beyond his or her perceived ability to cope. According to the stressor-strain perspective, job stressors are the stimuli that induce the stress process, and forms of strain, such as tension, anxiety, and exhaustion, are the proximal outcomes of this process (Jex, 1998). Recent research has found that although all stressors appear to cause strain, different types of stressors are associated with different affective and behavioral responses.

Based on the nature of stressor, Cavanaugh, Boswell, Roehling, and Boudreau (2000) partitioned job stressors into two types. One type included demands such as time urgency, high workload, and job responsibility. This type was labeled as challenge stressors because it included stressful demands viewed by individuals as opportunities for growth, learning, and achievement. The other included demands such as organizational politics, red tape, role ambiguity, and concerns about job security. This type was labeled as hindrance stressors because it included stressful demands viewed by individuals as obstacles to personal growth and goal attainment.

Employees tend to regard challenge stressors as potential reciprocity norms established by their organizations. Organizations offer challenge stressors with potential valuable outcomes. If employees can overcome the stressors, they may receive material and spiritual rewards (Cavanaugh et al., 2000; LePine et al., 2005). Zhang, Lepine, Buckman, \& Feng (2014) indicated that challenge stressors such as workload and responsibility can improve employees' perception of organizational justice. Thus, employees who are under challenge stressors tend to identify and obey the reciprocity norm. For example, employees with high levels of responsibility tend to recognize this kind of stressor as an investment for potential return ((Podsakoff et al., 2007). They may be sensitive to the social exchange and actively respond to organizational support. Furthermore, if employees actually overcome the challenge stressors, they can gain rewards from the organization.

Challenge and hindrance stressors were found to differentially associated with employees' job attitudes, cognitions, and behaviors (Boswell, Olson-Buchanan, \& LePine, 2004; Cavanaugh et al, 2000; LePine, Podsakoff, \& LePine, 2005). Challenge stressors elicit positive emotions and active problem-focused coping style (Crawford, LePine, \& Rich, 2010). Therefore, they were found to have positive effects on organizational outcomes, such as job satisfaction, organizational commitment, and performance (LePine et al., 2005).

Concerning employees' innovative behavior, it was suggested that employees considered innovative activities as an effective way of dealing with a heavy workload (Bunce \& West, 1994). Based on person-environment fit theory (Ryhammar \& Smith, 1999; Stokols, Clitheroe, \& Zmuidzinas, 2002), innovative behavior may help employees to improve their fit with high job challenges by generating, promoting, and realizing ideas for modifying oneself or the work environment (Janssen, 2000). These findings suggested that idea generation and implementation might serve as effective coping strategies to challenge stressors. In contrast to challenge stressors, hindrance stressors are appraised as controlling and threatening. 


\section{Macrothink}

Previous studies have found that hindrance stressors had negative relationships with organizational outcomes, such as job satisfaction, organizational commitment, and performance (LePine et al., 2005). As for innovative behavior, idea generation and implementation might respond differently to hindrance stressors. Cowen (1952) found that psychological threat was associated with rigid thinking. In addition, more uncontrollability was found to decrease creative performance (Byron et al., 2010). Therefore, it might be the case that hindrance stressors hinder the generation of creative ideas. Compared with idea generation, idea implementation means putting the creative ideas into practice. It is likely that creative ideas are faced with skepticism and resistance as they challenge and violate the established frameworks of practices and the status quo in the organization (Janssen, Van de Vliert, \& West, 2004). To overcome these disincentives, sustained effort is required, yet the effort, to some extent, had to be motivated by uncertainty and threat of external environment (West, 2002). Some empirical studies also found that hindrance stressors, such as role conflict, role overload, and job ambiguity, lead to individual innovation (Martı'n, Salanova, \& Peiro', 2007). Therefore, it might be the case that hindrance stressors in organizations could serve as motivational source to foster the implementation of innovative ideas.

H28: Challenge Stressor have a negative and significant effect on employee's Quality of creativity

H31: Challenge Stressor have a negative and significant effect on employee's Quantity of creativity

H32: Hindrance Stressor have a negative and significant effect on employee's Quantity of creativity

H29: Hindrance Stressor have a negative and significant effect on employee's Quality of creativity

\section{Work pressure}

(Teresa M. Amabile et al., 1996) puts workload in a way that when workload occurs it comes with unrealistic expectations for the outcome, dead line pressures and makes it known as distraction from creative performance

Some research has found that, although workload pressures that were considered extreme could undermine creativity, some degree of pressure could have a positive influence if it was perceived as arising from the urgent, intellectually challenging nature of the problem itself (Amabile, 1988; Amabile \& Gryskiewicz, 1987). Similarly, Andrews and Farris (1972) found that time pressure was generally associated with high creativity in R\&D scientists, except when that pressure reached an undesirably high level. But time pressure that is perceived as a necessary concomitant of an important, urgent project may add to the perception of challenge in the work that positively correlates with intrinsic motivation and creativity (Amabile, 1988). H30: Work pressure have a negative and significant effect on employee's Quality of creativity H33: Work pressure have a negative and significant effect on employee's Quantity of creativity

\section{Quality \& Quantity of creativity}

Creative performance is defined as an individual's ability to generate novel and useful ideas regarding procedures and processes at work. 


\section{MInstitute Macrothink $^{m}$}

Theories regarding creativity climate have attempted to identify aspects of work environments that facilitate creativity, mainly from organizational perspective (Amabile et al., 1996). Ekvall and Ryhammar (1999) argued that creativity climate composes of challenge, freedom, and support; in addition, it encourages openness and the tolerance of uncertainty. Amabile's componential model (1988) of organizational creativity identified contextual components as essential to creativity climate, such as encouragement of creativity, autonomy, freedom, resources, pressures, and organizational impediments to creativity. This theoretical model led to the development of the "KEYS: Assessing the Climate for Creativity" as an instrument assessing organizational creativity climate that could facilitate interventions to promote innovation within organizations. Woodman et al. (1993) took a similar perspective on Amabile's view and comment further that an important feature of creativity context is its ability to address influences across different levels which can enhance or inhibit creative behavior in complex social systems. In addition, by integrating psychological and sociological descriptions of creativity, Ford (1996) proposed a theory of individual creative action within organizational settings. He pointed out that creativity in organizational settings could best be conceived in terms of creative actions that may be simultaneously influenced and assessed across multiple social domains within and between levels of analysis. Although climate perception originates from individuals, organizational members are typically exposed to the same work environment and other proximal influence. These perspectives regard creativity climate as employees' shared perceptions about the structure and practices occurring in organizations.

One can have ideas about importance of quantity (Tunc, 2012) and quality (Goodsir et al., 2014) of creativity. Some may think quantity of creativity is more important because it means the restaurant can regularly release new dishes to keep up the novelty (Tunc, 2012). On the other hand, quality of creativity can also be important in the way it leads to winning awards and thus contributing to the fame of a restaurant (Goodsir et al., 2014). Reference to unidimensionality in part relates to these two aspects of creativity being examined as single dependent variable (Füller et al., 2011). This study; however, proposed that different factors contribute differently to these two aspects of creative performance by examining the impact of independent variables on two dependent variables (i.e., the quantity and quality aspect of creativity).

\section{Innovation}

Innovation refers to the process of developing and implementing a new idea McLean, (2005) According to (Chang et al., 2011), innovation can be categorized into incremental and radical innovation. The former refers to minor improvement of current technology while the later refers to revolutionary changes. This paper essentially deals with incremental innovation.

Some studies proposed that creativity climate was an important predictor of organizational performance (see Amabile et al., 1996; Ekvall, 1996). Ismail (2005) found creative climate influence firm's innovation. Similarly, Tsai and Kao (2004) surveyed 254 employees from Taiwanese enterprises in which the employee have higher innovative behaviors when they perceived higher organizational creativity climate

Isaksen et al. (1999) asserted that climate for creativity promotes the generation, consideration, and use of new products, services and ways of working, as creativity climate 


\section{Macrothink}

supports the development, assimilation, and utilization of new and different approaches and concepts

H35: Quality of creativity have a positive and significant effect on Innovation

H37: Quantity of creativity have a positive and significant effect on Innovation

\section{Work Motivation}

To facilitate employees' work motivation, job design has long been considered an important contributor to employee work motivation, performance and satisfaction (Mitchell, 1982). Job Characteristics Theory (JCT) is conceptualized as a comprehensive model with five-core job dimensions, namely skill variety, task identity, task significance, autonomy and feedback. This model predicted that under certain conditions individuals who valued and experienced a job high on these dimensions were more likely to exhibit high work motivation, better attendance, and greater productivity and report higher levels of job satisfaction. Studies have suggested that creativity and innovation in products, work processes, and services are key contributors to long-term organizational survival and success (Teresa M. Amabile et al., 1996; SHALLEY, 1995; Yeh-Yun Lin \& Yi-Ching Chen, 2007; J. Zhou \& Shalley, 2008).

H34: Quality of creativity have a positive and significant effect on Motivation

H36: Quantity of creativity have a positive and significant effect on Motivation

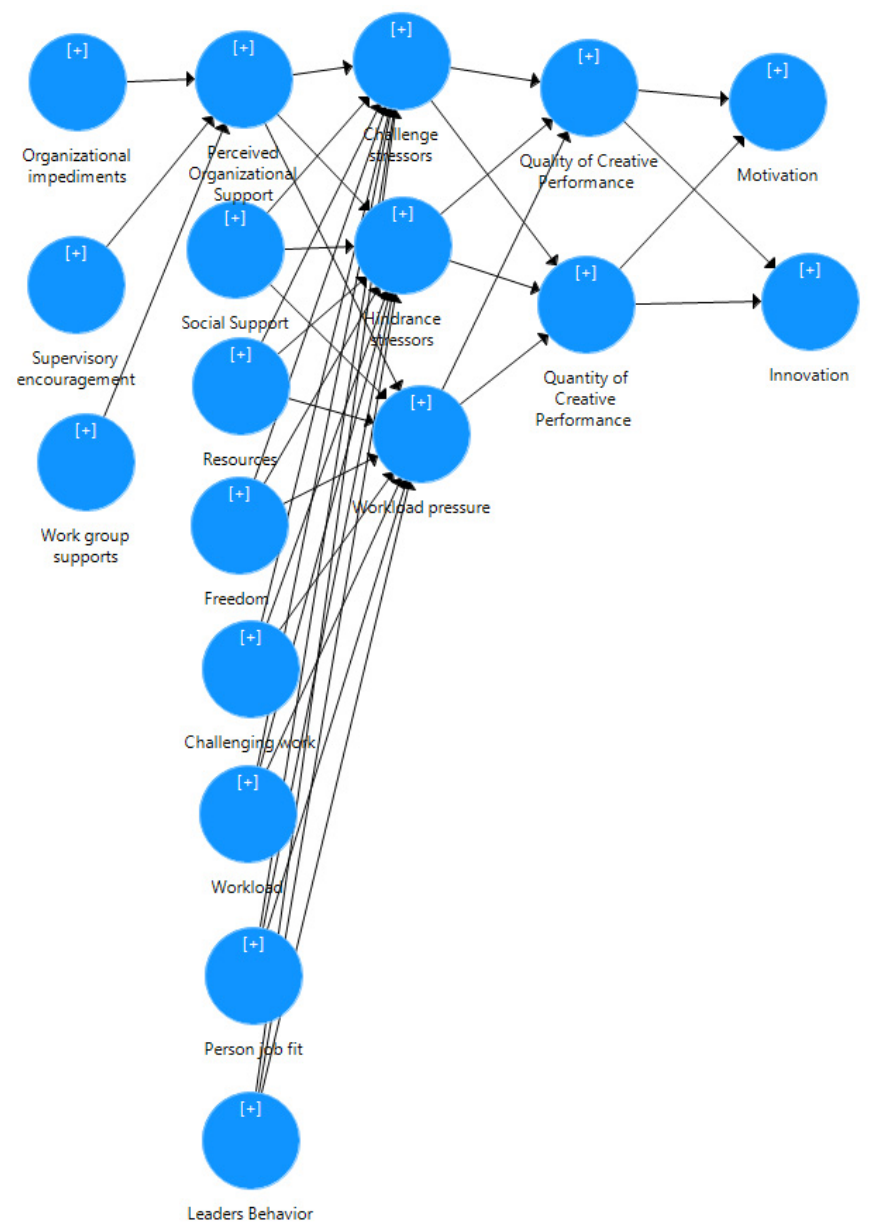




\section{Research Methodology}

We have conduct our research from those employees who are working in IT, Advertising and Educational sectors so our population is based on IT, Advertising and Educational workers. The reason of choose this population because in this field there are many new things is generated after some specific period of time and those employee who are updated and creative in their field so they are survive easily otherwise they manage hard in their field.

\subsection{Sample and Sampling Method}

In this research there are quantitative data, so we collect the information from 300 employees. We have done with convenient sampling method. And through this conclusion we generate the idea, that is; how much workload and pressure effect on the employee's creativity.

\subsection{Questionnaire Design}

This study in its nature is a quantitative research and based on primary data. To collect the primary data we merged and used questionnaire from of different researches which were in the same nature of our hypothesis and objectives. Such as for the cadre of "Resources" "Social Support" "Quantity of Creative Performance" and "Quality of Creative Performance" the questions were adopted from (Yeh \& Huan, 2017). While for the questions related to "person Job fit" were adopted from (Lauver \& Kristof-Brown, 2001). For the questions of "Perceived Organizational support" "Challenge Stressors" and "Hindrance stressors" we took help from the papers of Feifei \& Zhang (2015). While "Workload" questions were adopted from (F. \& Blau, 2007). And questions for "Leaders Behavior" were adopted from (Shao et al., 2019a). "Freedom" "Work Group Supports" Challenging Work" "Workload Pressure" "organizational impediments" and "Innovation" were adopted from Lin \& Liu, (2012). However the question for the "Motivation" cadre was adopted from (Hackman \& Oldham, 1976). We used 5 point Likert scale ranging from rates of 1 to 5 having strongly disagree $=1$. Disagree $=2$ Neutral $=3$ Agree $=4$ and Strongly Agree $=5$.

\section{Preliminary Analysis}

\subsection{Demographic Analysis}

\begin{tabular}{cccc}
\hline Variable & Category & Frequency & Percent \\
\hline & 20 to 25 & 97 & $32.33 \%$ \\
Age & 26 to 30 & 82 & $27.33 \%$ \\
& 31 to 35 & 57 & $19 \%$ \\
& 36 to 40 & 34 & $11.33 \%$ \\
& 41 to 45 & $26.66 \%$ \\
Gender & 45 above & 4 & $1.33 \%$ \\
\hline
\end{tabular}

In the above table it can be seen that most of the responses were collected from people aged 20 to 25 which gives a great reliability of understanding of respondents. The second highest 
responses were collected from people aging in 26 to 30 years old that happens to be 82 respondents taking $27 \%$ of sample. While 57 people who were aged between 31 to 35 years, responded to questionnaire occupying $19 \%$ of the sample. However people who were aged between 41 to 45 years, were 26 and filled out our questionnaires securing $8.66 \%$ of sample and lowest number of respondents were aged above 45 years.

\subsection{Descriptive Statistic}

\begin{tabular}{|c|c|c|c|c|c|c|c|}
\hline & \multicolumn{2}{|c|}{ Questions } & \multicolumn{2}{|c|}{$\begin{array}{l}\text { Descriptive } \\
\text { Stats }\end{array}$} & \multicolumn{2}{|c|}{$\begin{array}{l}\text { Confirmatory } \\
\text { Analysis }\end{array}$} & \multirow{2}{*}{$\begin{array}{l}\text { Factor } \\
\mathrm{P} \\
\text { Value }\end{array}$} \\
\hline & & & Mean & S.d & LOADING & Stats & \\
\hline \multirow{4}{*}{ Social support } & 1 & $\begin{array}{l}\text { Organization policy support social } \\
\text { activities }\end{array}$ & 2.74 & 1.26 & 0.889 & 14.260 & 0.00 \\
\hline & 2 & $\begin{array}{l}\text { I receive supervisory leadership for new } \\
\text { development }\end{array}$ & 2.95 & 1.12 & 0.704 & 34.106 & 0.00 \\
\hline & 3 & $\begin{array}{l}\text { I receive supervisory support for new } \\
\text { development }\end{array}$ & 2.96 & 1.20 & 0.904 & 35.095 & 0.00 \\
\hline & 4 & $\begin{array}{l}\text { Strong atmosphere for new development } \\
\text { amongst co-workers }\end{array}$ & 3.00 & 1.18 & 0.886 & 31.089 & 0.00 \\
\hline \multirow{3}{*}{ Workload } & 1 & $\begin{array}{l}\text { I can choose not to accept assignments } \\
\text { based on my current workload }\end{array}$ & 2.93 & 1.14 & 0.688 & 25.472 & 0.00 \\
\hline & 2 & $\begin{array}{l}\text { I have control over the work directed to my } \\
\text { subordinates }\end{array}$ & 2.88 & 1.05 & 0.721 & 24.392 & 0.00 \\
\hline & 3 & $\begin{array}{l}\text { I do not answer phones or look at e-mail } \\
\text { while dedicating efforts toward a particular } \\
\text { assignment }\end{array}$ & 2.92 & 1.13 & 0.927 & 43.836 & 0.00 \\
\hline \multirow{3}{*}{ Resources } & 1 & $\begin{array}{l}\text { Organization provide source of inspiration } \\
\text { for new development }\end{array}$ & 3.18 & 1.05 & 0.905 & 63.111 & 0.00 \\
\hline & 2 & $\begin{array}{l}\text { Organization elicit outside support for new } \\
\text { development }\end{array}$ & 2.95 & 1.06 & 0.801 & 57.232 & 0.00 \\
\hline & 3 & $\begin{array}{l}\text { Organization possess facilities for new } \\
\text { development }\end{array}$ & 3.11 & 1.10 & 0.889 & 67.126 & 0.00 \\
\hline \multirow{3}{*}{ Freedom } & 1 & $\begin{array}{l}\text { I have the freedom to decide how I am } \\
\text { going to carry out my project }\end{array}$ & 3.03 & 1.28 & 0.619 & 14.886 & 0.00 \\
\hline & 2 & $\begin{array}{l}\text { Freedom in deciding what work to do or } \\
\text { how to do it }\end{array}$ & 3.31 & 1.02 & 0.805 & 41.749 & 0.00 \\
\hline & 3 & $\begin{array}{l}\text { Freedom give sense of control over one's } \\
\text { work }\end{array}$ & 3.27 & 1.12 & 0.828 & 40.751 & 0.00 \\
\hline \multirow{2}{*}{$\begin{array}{l}\text { Quantity of creative } \\
\text { performance }\end{array}$} & 1 & I regularly create new ideas & 3.31 & 1.10 & 0.876 & 100.62 & $\mathbf{0 . 0 0}$ \\
\hline & 2 & I can create very fast if necessary & 3.19 & 1.11 & 0.866 & 20.951 & 0.00 \\
\hline \multirow{2}{*}{$\begin{array}{l}\text { Quality of creative } \\
\text { performance }\end{array}$} & 1 & My new development often win awards & 3.29 & 1.10 & 0.707 & 14.581 & 0.00 \\
\hline & 2 & My new development are popular amongst & 3.19 & 1.08 & 0.726 & 18.283 & 0.00 \\
\hline
\end{tabular}


Person job fit

Perceived

organization support

Challenge stressors

Hindrance stressor

Leaders behaviour

encouragement

customers

1 My abilities fit the demands of this job

3.50

$1.16 \quad 0.652$

25.185

$\mathbf{0 . 0 0}$

2

I have the right skills and abilities for doing this job

3.32

$1.18 \quad 0.601$

$24.620 \quad 0.00$

3 There is a good match between the requirements of this job and my skills

3.47

$\begin{array}{ll}1.17 & 0.627\end{array}$

$24.875 \quad \mathbf{0 . 0 0}$

4 My personality is a good match for this job

3.3

$1.19 \quad 0.623$

$23.179 \quad \mathbf{0 . 0 0}$

5 I am the right type of person for this type of work

3.3

$1.19 \quad 0.730$

$23.341 \quad 0.00$ The organization is willing to help me when I need a special favor for me

3 The organization strongly considers my goals and values

1 The number of projects and or assignments I have

2 The amount of time I spend at work

3 The volume of work that must be accomplished in the allotted time

4 Time pressures I experience

5 The amount of responsibility I have

6 The scope of responsibility my position entails The inability to clearly understand what is expected of me on the job

The amount of red tape I need to go through to get my job done

3 The lack of job security I have The degree to which my career seems stalled

Clarifies work requirements, but does not

micro-manage work

Makes final decisions for subordinates, but

2 allows subordinates to control specific work processes

1 My supervisor sets goals appropriately

2 My supervisor shows confidence in the work group

3 My supervisor serves as a good work model

$\begin{array}{lllll}3.36 & 1.13 & 0.667 & 37.782 & 0.00\end{array}$

$\begin{array}{lllll}3.21 & 1.13 & \mathbf{0 . 6 5 2} & 24.095 & \mathbf{0 . 0 0}\end{array}$

$\begin{array}{lllll}3.22 & 1.11 & 0.647 & 12.798 & 0.00\end{array}$

$\begin{array}{lllll}3.25 & 0.98 & 0.839 & 33.311 & 0.00\end{array}$

$\begin{array}{lllll}3.36 & 1.06 & 0.831 & 46.722 & 0.00\end{array}$

$\begin{array}{lllll}3.31 & 1.03 & \mathbf{0 . 8 8 3} & 67.936 & \mathbf{0 . 0 0}\end{array}$

$\begin{array}{lllll}3.34 & 1.08 & 0.849 & 53.139 & 0.00\end{array}$

$\begin{array}{lllll}3.32 & 1.11 & 0.813 & 52.621 & 0.00\end{array}$

$\begin{array}{lllll}3.39 & 1.08 & \mathbf{0 . 8 9 4} & 59.711 & \mathbf{0 . 0 0}\end{array}$

$\begin{array}{lllll}3.29 & 1.05 & 0.855 & 49.996 & 0.00\end{array}$

$\begin{array}{lllll}3.17 & 1.01 & 0.844 & 39.524 & 0.00\end{array}$

$\begin{array}{lllll}3.20 & 1.05 & 0.737 & 46.647 & \mathbf{0 . 0 0}\end{array}$

$\begin{array}{lllll}3.23 & 1.06 & 0.828 & 43.466 & 0.00\end{array}$

$\begin{array}{lllll}3.32 & 1.04 & 0.796 & 55.730 & 0.00\end{array}$

$\begin{array}{lllll}3.23 & 1.04 & 0.852 & 75.019 & \mathbf{0 . 0 0}\end{array}$

$\begin{array}{lllll}3.36 & 1.12 & 0.719 & 31.160 & 0.00\end{array}$

$\begin{array}{lllll}3.35 & 1.17 & 0.635 & 28.538 & 0.00\end{array}$

$\begin{array}{lllll}3.39 & 1.19 & \mathbf{0 . 6 7 9} & 11.637 & \mathbf{0 . 0 0}\end{array}$ 


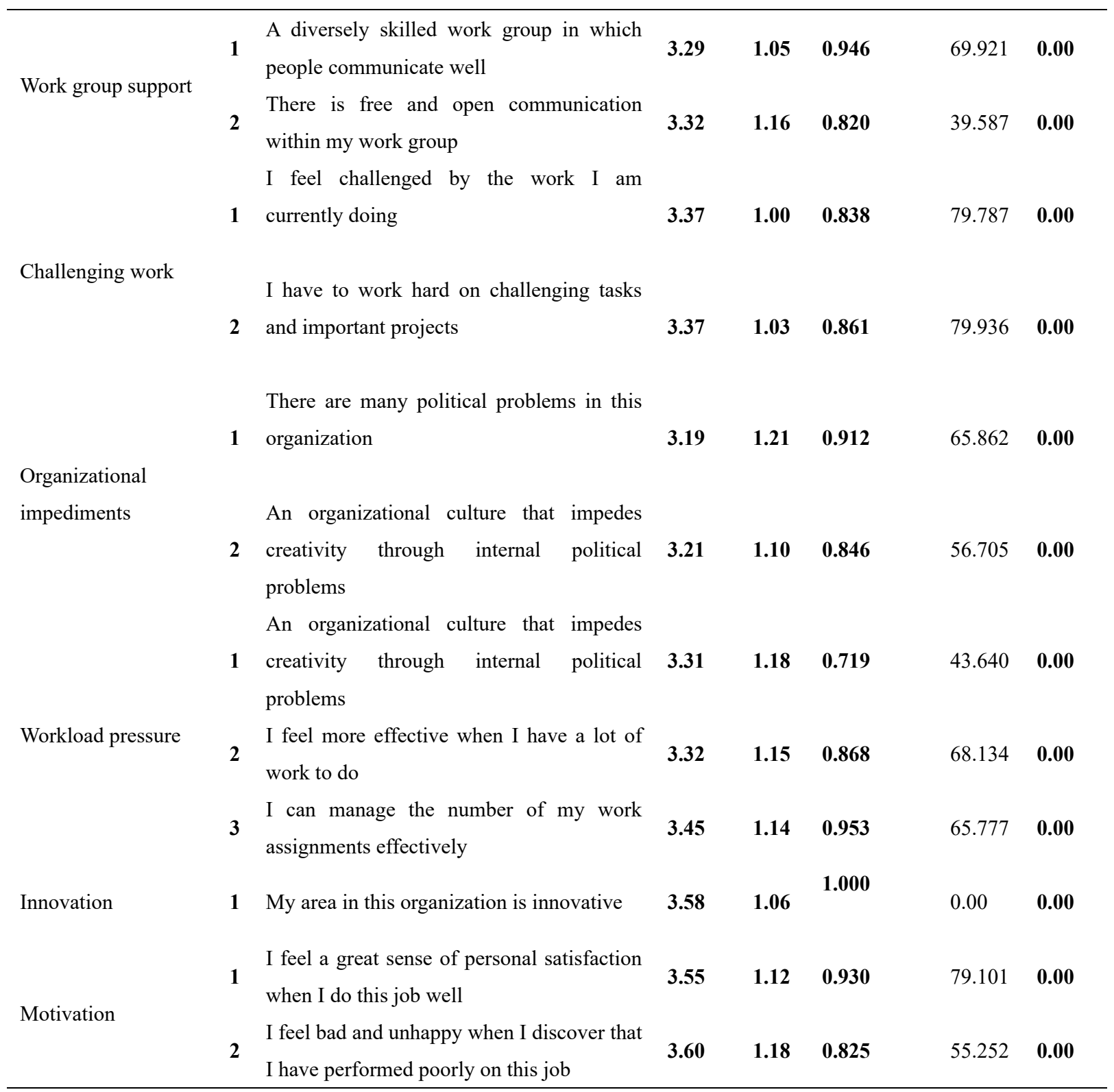

In the above table it can be seen that for social support we have means between 2.74 to 3.00 while the highest means in this cadre is of $4^{\text {th }}$ question but has relatively low standard deviation the lowest mean of $1^{\text {st }}$ question while the first question has the highest standard deviation. So respondents had greater average response with respect to the social support in the organization. For questions of workload it has means starting from 2.932 .88 and 2.92 for question 1,2 , and 3 respectively while every question has standard deviation from 1.14, 1.05 and 1.13 for the questions 1,2 and 3 respectively. In questions for Resources of questions is 3.182 .95 and 3.11 relatively higher than previous set of question. It shows that when it comes to resources organization tend to be more resourceful than being work loaders. While in Freedom the total mean of 3.20 again relatively higher than the previous cadres, it is identified that companies are more lenient than resourceful, when it comes to freedom of the employees in their decision making for the work they are given. For Quantity of Creative Performance set of question a total mean of 3.25 was identified where respondents were more 


\section{MInstitute ${ }^{\text {Macrothink }}$}

in line with their creativity and innovation while the standard deviation was 1.10 and 1.11 . In Quality of Creative Performance the recognition of the work can be observed through these questions where the respondents' total mean is 3.24 relatively lower than previous set of question related to quantity of creative performance. One of the very crucial elements for the creativity has been the right man for the right job while the total mean for Person Job fit 3.40 relatively higher than all the previous cadre depicts that most of the respondents were in line with their jobs and role they were working in. In Questions for Perceived Organizational Support these question where a number of questions were asked to observe weather in organization perceived support is available to employees. The answers have given standard deviation of 1.13 .1.3 and 1.11 lower than the means of respective question, signifies that people perceived organizational support closely. While in Challenge stressors the total mean for challenge stressors is 3.32 and standard deviation is $0.98,1.06,1.03,1.081 .11$ and 1.08 in this cadre of questions respectively. Such values depicts that there is high number of challenge stressor in our respondents. In Hindrance Stressors question the total mean is 3.22 and standard deviation is $1.05,1.01 .1 .05$, and 1.06 respectively shows there are clustered hindrance stressors which often suppress their ability to creativity. The two question of Leaders Behavior a total mean of 3.27 is there and standard deviation of 1.04 for both, shows leaders tend to be little deviated from behavior required than behaviors provided. In Supervisory encouragement set of question the mean is 3.36 and standard deviation is 1.12, 1.17 and 1.19 respectively. On the questions of team work support we have calculated a total mean of 3.30 and standard deviation of 1.05 and 1.16 respectively. The responses over the questions of challenging work are fascinating where a total mean is 3.37 and an exact S.D. of 1.00 in the first depicts that respondents are quiet in line with their work challenges.

In Organizational impediments question we have calculated a total mean of 3.32 and S.D. of 1.21 and 1.10 relatively higher than previous group of question that shows there is a hindrance in organization. In Workload pressure group of questions we have 3.37 as total mean and S.D. of 1.181 .15 and 1.14 respectively. A higher number S.D. shows the deviation of workload may be different. While people perceived their role innovative in their organizations with a total mean of 3.58 and little deviation of 1.06 was observed. The last question two questions were related to motivation and has one of the highest total mean of 3.57 which shows that people are quiet motivated when they attain an their targets while a deviation of 1.12 and 1.18 was observed.

\subsection{Structural Equation Modeling}

To test the study hypothesis we have used the structural equation model (SEM) whereas the testing has been gone through Smart PLS software. Moreover, to evaluate the indirect and direct effects of all the constructs the testing was done. The use of (SEM) structural equation model has been observed to be a foremost procedure that has been used below different regression models and methods (Barron, R., Kenny, 1986) It used to evaluate the structural relationship between exogenous and endogenous variables. It includes factor analysis and multivariate analysis. Moreover, the equation of regression targets at explaining each construct to assess the cause and effect relationship while all of the factors in the causal model could demonstrate their cause and effect at exact time. Likewise, the idea of using this model ensures to apply technique of bootstrapping which has been viewed as reasonable for 


\section{Macrothink

both small and large sample size and does not require any kind of indirect effect. In order to check the all direct and indirect effects, a technique has been implemented which is known as bootstrapping (Shrout \& Bolger, 2002).

\subsection{Measurement of Outer Model}

The goal of measure of fit in the measurement model is to study about the reliability and validity of the instrument and to check its reliability and validity we perform test of convergent validity and discriminant validity in software naming Smart PLS.

\subsection{Composite Reliability}

Reliability implies stability of questionnaire outcomes. For the similar target population, at whatever point the questioner reutilize the questionnaire it will give similar outcome. It demonstrates inside consistency \& repeatability of the survey is high. The primary measure for unwavering quality is to maintain a strategic distance from unfairness in research. In this manner, it tends to be improved by testing the pursuit procedure and investigation, as is done utilizing diverse research and examination techniques or different researchers. This also incorporates the dependability and legitimacy of the exploration.

Reliability of the measurement instruments was evaluated using composite reliability. All the values were above the normally used threshold value i.e. 0.70 . This is the accepted reliability value range. Estimation of reliability can be done by degree of constancy that lies amongst various variables (Hair, 2010). Below is the table of composite reliability.

\begin{tabular}{|c|c|}
\hline Variables & Composite Reliability \\
\hline Social Support & 0.911 \\
\hline Workload & 0.826 \\
\hline Resources & 0.900 \\
\hline Freedom & 0.798 \\
\hline Quantity of Creative Performance & 0.863 \\
\hline Quality of Creative Performance & 0.790 \\
\hline Person job fit & 0.889 \\
\hline Perceived Organizational Support & 0.694 \\
\hline Challenge stressors. & 0.941 \\
\hline Hindrance stressors & 0.889 \\
\hline Leaders Behavior & 0.810 \\
\hline Supervisory encouragement & 0.719 \\
\hline Work group supports & 0.878 \\
\hline Challenging work & 0.838 \\
\hline Organizational impediments & 0.872 \\
\hline Workload pressure & 0.887 \\
\hline
\end{tabular}




\subsection{Factor Loadings Significant}

Table of descriptive statistics also mentioned loadings used in (CFA) confirmatory factor analysis. Construct with the loading of .5 are consider as strong loading variables whereas the constructs with the loading of below .5 are considered as less are better to be removed from the table.

\subsection{Convergent Validity}

Convergent validity is the level of agreement in at least two measures of a similar construct (Carmines \& Zeller, 1979). Convergent validity was assessed by inspection of variance mined for each factor (Fornell \& Larcker, 1981). Conferring to Fornell and Larcker (1981) if the, variance extracted value is greater than 0.5 then convergent validity is established and the result is drawn that the loadings are good but less than 0.5 are termed as less effective for the study.

Following table displays the result.

\subsection{Construct Reliability and Validity}

\begin{tabular}{ccccc}
\hline & Cronbach's Alpha & rho_A & Composite Reliability & Average Variance Extracted (AVE) \\
\hline Challenge stressors & 0.941 & 0.941 & 0.941 & 0.726 \\
Challenging work & 0.838 & 0.839 & 0.838 & 0.722 \\
Freedom & 0.788 & 0.812 & 0.798 & 0.572 \\
Hindrance stressors & 0.89 & 0.892 & 0.889 & 0.668 \\
Innovation & 1 & 1 & 1 & 1 \\
Leaders Behavior & 0.809 & 0.811 & 0.81 & 0.68 \\
Motivation & 0.868 & 0.877 & 0.872 & 0.773 \\
Organizational impediments & 0.871 & 0.874 & 0.872 & 0.773 \\
Perceived Organizational Support & 0.692 & 0.694 & 0.694 & 0.43 \\
Person job fit & 0.895 & 0.892 & 0.889 & 0.472 \\
Quality of Creative Performance & 0.79 & 0.793 & 0.79 & 0.486 \\
Quantity of Creative Performance & 0.863 & 0.863 & 0.863 & 0.759 \\
Resources & 0.9 & 0.903 & 0.9 & 0.751 \\
Social Support & 0.914 & 0.919 & 0.911 & 0.722 \\
Supervisory encouragement & 0.719 & 0.721 & 0.719 & 0.461 \\
Work group supports & 0.873 & 0.886 & 0.878 & 0.783 \\
Workload & 0.824 & 0.847 & 0.826 & 0.618 \\
Workload pressure & 0.886 & 0.901 & 0.887 & 0.726 \\
\hline
\end{tabular}

\subsection{Discriminant Validity}

Discriminate validity can be defined as any single construct when differs from other 


\section{I Macrothink}

Human Resource Research

ISSN 1948-5441

2020, Vol. 4, No. 1

constructs in the model (EG Carmines, 1979). Discriminate validity results are satisfactory when the constructs are having an AVE loading more than 0.5 which means that minimum $50 \%$ of variance was took by the construct (Chin, 1998). Discriminate validity is established if the elements which are in diagonal are significantly higher than those values in off-diagonal in the parallel rows and columns. Discriminant Validity tests are being conducted in order to see whether non-related ideas or measurements are in fact unrelated or not. An effective assessment of discriminant legitimacy demonstrates that a trial of an idea isn't exceptionally associated with different tests intended to quantify hypothetically various ideas. The table for Discriminant Validity is given below:

\begin{tabular}{|c|c|c|c|c|c|c|c|c|c|c|c|c|c|c|c|c|c|c|}
\hline & 1 & 2 & 3 & 4 & 5 & 6 & 7 & 8 & 9 & 10 & 11 & 12 & 13 & 14 & 15 & 16 & 17 & 18 \\
\hline \multicolumn{19}{|l|}{ Challenge stressors 1} \\
\hline Challenging work 2 & 0.362 & 0.850 & & & & & & & & & & & & & & & & \\
\hline Freedom 3 & 0.376 & 0.296 & 0.756 & & & & & & & & & & & & & & & \\
\hline Hindrance stressors 4 & 0.423 & 0.307 & 0.208 & 0.817 & & & & & & & & & & & & & & \\
\hline Innovation 5 & 0.304 & 0.389 & 0.284 & 0.277 & 1.000 & & & & & & & & & & & & & \\
\hline Leaders Behavior 6 & 0.533 & 0.508 & 0.384 & 0.464 & 0.306 & 0.825 & & & & & & & & & & & & \\
\hline Motivation 7 & 0.253 & 0.539 & 0.349 & 0.138 & 0.493 & 0.452 & 0.879 & & & & & & & & & & & \\
\hline Organizational impediments 8 & 0.167 & 0.463 & 0.129 & 0.423 & 0.261 & 0.299 & 0.220 & 0.879 & & & & & & & & & & \\
\hline Perceived Organizational Support 9 & 0.529 & 0.364 & 0.526 & 0.497 & 0.297 & 0.493 & 0.299 & 0.272 & 0.656 & & & & & & & & & \\
\hline Person job fit 10 & 0.394 & 0.391 & 0.565 & 0.362 & 0.353 & 0.453 & 0.358 & 0.158 & 0.545 & 0.687 & & & & & & & & \\
\hline Quality of Creative 11 & 0.365 & 0.330 & 0.578 & 0.408 & 0.410 & 0.414 & 0.296 & 0.191 & 0.502 & 0.953 & 0.697 & & & & & & & \\
\hline Quantity of Creative 12 & 0.282 & 0.315 & 0.475 & 0.298 & 0.349 & 0.342 & 0.266 & 0.132 & 0.313 & 0.861 & 1.026 & 0.871 & & & & & & \\
\hline Resources 13 & 0.126 & 0.342 & 0.371 & 0.233 & 0.360 & 0.095 & 0.343 & 0.146 & 0.280 & 0.289 & 0.262 & 0.202 & 0.867 & & & & & \\
\hline Social Support 14 & 0.120 & 0.363 & 0.307 & 0.158 & 0.168 & 0.202 & 0.281 & 0.114 & 0.287 & 0.335 & 0.303 & 0.279 & 0.478 & 0.850 & & & & \\
\hline Supervisory encourage 15 & 0.374 & 0.516 & 0.433 & 0.510 & 0.449 & 0.706 & 0.579 & 0.183 & 0.626 & 0.574 & 0.460 & 0.379 & 0.341 & 0.380 & 0.679 & & & \\
\hline Work group supports 16 & 0.185 & 0.530 & 0.348 & 0.240 & 0.339 & 0.317 & 0.589 & 0.229 & 0.291 & 0.349 & 0.182 & 0.234 & 0.459 & 0.331 & 0.652 & 0.885 & & \\
\hline Workload 17 & 0.165 & 0.412 & 0.370 & 0.196 & 0.210 & 0.267 & 0.301 & 0.208 & 0.237 & 0.332 & 0.273 & 0.222 & 0.563 & 0.452 & 0.330 & 0.377 & 0.786 & \\
\hline Workload pressure 18 & 0.368 & 0.563 & 0.284 & 0.367 & 0.280 & 0.369 & 0.387 & 0.448 & 0.297 & 0.313 & 0.362 & 0.324 & 0.287 & 0.203 & 0.392 & 0.360 & 0.262 & 0.852 \\
\hline
\end{tabular}

\subsection{Hypothesis Testing}

In PLS-SEM, bootstrapping is one of the key stride, which gives the data of constancy of factor guesstimate. Sub-tests are drawn everywhere from the first example including substitution, in this process (Hair, Matthews, Matthews, \& Sarstedt, 2017). Bootstrapping provides the information of stability of coefficient estimate. In this process, a large number of sub-samples are drawn from the original sample with replacement (Hair et al. 2016). After running the bootstrap routine, SmartPLS shows the t-values for structural model estimates derived from the bootstrapping procedure. The results of path coefficients for all the hypothesis are shown in the following table. The $t$-value greater than $1.96(p<.005)$ shows that the relationship is significant at $95 \%$ confidence level $(\alpha=0.05)$. Paths showing whether 


\section{Macrothink}

Human Resource Research

ISSN 1948-5441

2020, Vol. 4, No. 1

the relationship between measured and latent variables are significant or not.

\section{Result}

Path coefficient analysis (statically analysis) is used to determine the effects of variables.

\begin{tabular}{|c|c|c|}
\hline Relations & T Statistics $(|\mathrm{O} / \mathrm{STDEV}|)$ & P Values \\
\hline Challenge stressors $\geq$ Quality of Creative Performance & 2.338 & 0.020 \\
\hline Challenge stressors $\geq$ Quantity of Creative Performance & 1.520 & 0.129 \\
\hline Challenging work $\geq$ Challenge stressors & 1.811 & 0.071 \\
\hline Challenging work $\geq$ Hindrance stressors & 0.541 & 0.589 \\
\hline Challenging work $\geq$ Workload pressure & 6.231 & 0.000 \\
\hline Freedom $\geq$ Challenge stressors & 1.269 & 0.205 \\
\hline Freedom $\geq$ Hindrance stressors & 1.593 & 0.112 \\
\hline Freedom $\geq$ Workload pressure & 0.699 & 0.485 \\
\hline Hindrance stressors $\geq$ Quality of Creative Performance & 3.168 & 0.002 \\
\hline Hindrance stressors $\geq$ Quantity of Creative Performance & 1.981 & 0.048 \\
\hline Leaders Behavior $\geq$ Challenge stressors & 4.127 & 0.000 \\
\hline Leaders Behavior__ $\geq$ Hindrance stressors & 3.393 & 0.001 \\
\hline Leaders Behavior__ $\geq$ Workload pressure__ & 1.318 & 0.188 \\
\hline Organizational impediments $\geq$ Perceived Organizational Support & 2.634 & 0.009 \\
\hline Perceived Organizational Support__ $\geq$ Challenge stressors & 3.376 & 0.001 \\
\hline Perceived Organizational Support__ $\geq$ Hindrance stressors & 3.887 & 0.000 \\
\hline Perceived Organizational Support__ $\geq$ Workload pressure & 0.363 & 0.717 \\
\hline Person job fit $\geq$ Challenge stressors & 1.065 & 0.287 \\
\hline Person job fit $\geq$ Hindrance stressors & 1.673 & 0.095 \\
\hline Person job fit $\geq$ Workload pressure & 0.725 & 0.469 \\
\hline Quality of Creative Performance $\geq$ Innovation & 2.608 & 0.009 \\
\hline Quality of Creative Performance $\geq$ Motivation & 1.469 & 0.142 \\
\hline Quantity of Creative Performance $\geq$ Innovation & 0.414 & 0.679 \\
\hline Quantity of Creative Performance $\geq$ Motivation & 0.605 & 0.546 \\
\hline Resources $\geq$ Challenge stressors & 0.099 & 0.921 \\
\hline Resources $\geq$ Hindrance stressors & 1.447 & 0.148 \\
\hline Resources $\geq$ Workload pressure _ & 1.209 & 0.227 \\
\hline Social Support $\geq$ Challenge stressors & 1.008 & 0.314 \\
\hline Social Support $\geq$ Hindrance stressors & 0.542 & 0.588 \\
\hline Social Support $\geq$ Workload pressure & 0.539 & 0.590 \\
\hline Supervisory encouragement $\geq$ Perceived Organizational Support & 6.082 & 0.000 \\
\hline Work group supports $\geq$ Perceived Organizational Support & 0.412 & 0.680 \\
\hline
\end{tabular}


Workload $\geq$ Hindrance stressors

Workload $\geq$ Workload pressure

The above results show that relationship between the variables which shows the significant impact of variable on other variables. Details are given below:

Challenge stressors creates positive significant impact on Quality of Creative Performance with T- Value of 2.338, while Challenge stressors creates negative significant impact on Quantity of Creative Performance with T-value of 1.520. Challenging work creates a negative significant impact on Challenge stressors and hindrance stressor with T-values of 1.811 and 0.541 respectively. While Challenging work creates a positive significant impact on workload pressure with $\mathrm{T}$ value of 6.231 . Freedom creates a negative significant impact on challenge stressor, Hindrance stressor and workload pressure with T-values of 1.269, 1.593 and 0.699 respectively. Hindrance stressors creates a positive significant impact on Quality of creative performance and Quantity of creative performance with T-values of 3.168 and 1.98 respectively. Leaders Behavior creates a positive significant impact on challenge stressor and Hindrance stressor having T-value of 4.127 and 3.393 respectively. However, Leaders behavior shows negative significant impact on workload pressure having T-value of 1.318. Organizational impediments value shows the positive significant impact on Perceived Organizational Support creating a T-value of 2.634. Perceived Organizational Support creates a positive significant impact on challenge stressor having a T-value 3.376 and also on Hindrance stressor forming a T-value of 3.887 however it has negative significant impact on workload pressure with T-value of 0.363 . Person job fit values depicts a negative significant impact creates on Challenge stressor, Hindrance stressor and Workload pressure having T-values of $1.065,1.673$ and 0.725 respectively. Quality of Creative Performance creates a positive significant impact with innovation having T-values of 2.608 and a negative significant impact with motivation producing a T-value of 1.469. Quantity of Creative Performance creates a negative significant impact with Innovation and Motivation having T-values of 0.414 and 0.605 respectively. Resources creates and Social Support creates a negative significant impact on challenge stressors, Hindrance stressor and Workload pressure with T-values of $0.099,1.447$ and 1.209 respectively. Social support has negative significant impact over Challenge stressor, Hindrance stressor and workload pressure 1.008, 0.542 and 0.539 respectively. Supervisory encouragement creates a positive significant impact on Perceived Organizational Support with T-value of 6.082. While work group support creates a positive significant impact on Perceived Organizational Support with T-value 0.412. Workload creates a negative impact on challenge stressors, Hindrance stressors and workload pressure having T-values of $0.303,0.061$ and 0.098 respectively. Workload pressure creates a positively significant impact on Quality of Creative Performance and the Quantity of creative performance having T-values of 2.415 and 2.284 . 


\section{Macrothink}

Human Resource Research

ISSN 1948-5441

2020, Vol. 4, No. 1

Mediation Effects

\begin{tabular}{|c|c|c|c|}
\hline & Original Sample $(\mathrm{O})$ & T Stat & P Values \\
\hline Supervisory encouragement $\geq$ Perceived Organizational Support__ $\geq$ Challenge stressors & 0.101 & 2.840 & 0.005 \\
\hline Organizational impediments $\geq$ Perceived Organizational Support__ $\geq$ Hindrance stressors & 0.038 & 1.979 & 0.048 \\
\hline Supervisory encouragement $\geq$ Perceived Organizational Support__ $\geq$ Hindrance stressors & 0.108 & 3.165 & 0.002 \\
\hline Leaders Behavior__ $\geq$ Challenge stressors $\geq$ Quality of Creative Performance & 0.048 & 2.013 & 0.045 \\
\hline Perceived Organizational Support__ $\geq$ Challenge stressors $\geq$ Quality of Creative Performance & 0.040 & 1.980 & 0.048 \\
\hline Leaders Behavior__ $\geq$ Hindrance stressors $\geq$ Quality of Creative Performance & 0.058 & 2.104 & 0.036 \\
\hline Supervisory encouragement $\geq$ Perceived Organizational Support_ $\geq$ Hindrance stressors & 0.024 & 2.193 & 0.029 \\
\hline \multicolumn{4}{|l|}{$\geq$ Quality of Creative Performance } \\
\hline Perceived Organizational Support__ $\geq$ Hindrance stressors $\geq$ Quality of Creative Performance & 0.054 & 2.595 & 0.010 \\
\hline Challenging work $\geq$ Workload pressure__ $\geq$ Quality of Creative Performance & 0.068 & 2.228 & 0.026 \\
\hline Perceived Organizational Support__ $\geq$ Hindrance stressors $\geq$ Quantity of Creative Performance & 0.036 & 1.980 & 0.048 \\
\hline Challenging work $\geq$ Workload pressure $\geq$ Quantity of Creative Performance & 0.075 & 2.113 & 0.035 \\
\hline
\end{tabular}

\section{Discussions}

The main aim of this study is to identify the consequences of workload on employee creativity. The findings of the research suggest that workload is affecting the employee creativity in a negative way. Our results are in line with several authors such as Hon \& Kim, (2007) denoted that the higher level of workload can influence the creativity of the individual. The consequent of workload is not in the favor of employee productivity therefore the result show the significantly partially negative relationship between workload and creativity of employee. However as in organizational impediments and workload pressure results are not in line with (Lin \& Liu, 2012). Meanwhile, the results are showing that challenge stressors have positive impact on the quality of creativity on the other hand it denotes negative impact on the quantity of creativity that means the quality of creativity can be effected when there are greater challenge stressors and quantity remains unaffected regardless of challenge stressors. Based on the POS theory, employees' belief towards their organization about how well their organization recognize their contributions as well as to what extent organizations show care for their well-being and satisfies their socio-emotional needs (Eisenberger et al., 2016) in our research the results regarding the perceived organizational support; results show that there is positive relation with creativity however these results are in consistency with (L. Zhang et al., 2018) and he further argues that there is reciprocity of duties of employees and support of organization, which creates mechanism of an exchange which is an expected result; that perceived organizational support and workload pressure does not have any positive relation. However hindrance stressors have positive impact on both quality and quantity of performance therefore in relation with (Yu \& Frenkel, 2012) we observe peculiarities between our research and his. Based on the leadership behavior we see that the impact over the hindrance and challenge stressor is positive this is in line with the results of (Shao et al., 


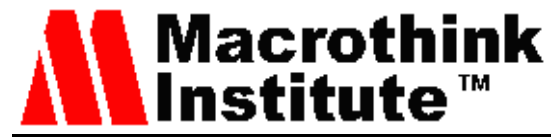

2019b) where he argues that control, autonomy and constrains and flexibility can influence the creative performance of employee in situations of high workload. However the impact of challenging work has negative impact on the hindrance and challenge stressor but a positive impact can be seen on workload pressure as far as innovation is concerned our results are not aligned with Lin \& Liu (2012) where workload pressure is failing to show any impact. While in the same paper some of our results are in aligned concerning with Freedom where freedom fails to create a positive relation with innovation and the other supervisory engagement becoming stimulant of innovation. With regard to social support Yeh \& Huan, (2017) found that social support is positively contributing to creativity of employees while in our results we see that does not have any appositive impact on challenge $\&$ hindrance stressors therefore based on the results of challenge and hindrance stressors earlier, having positive impact on quality and negative on quantity of creativity and later having positive relationship. As far as hypothesis for person job fit are concerned our results show negative impact of P-J fit on Challenge and Hindrance Stressors and workload pressure which is agreeable with findings of (Lauver \& Kristof-Brown, 2001) where they found no significant relation of Person job fit with task performance.

\section{Conclusion}

The creativity of an organization's individuals and groups is the driving force of innovation and change. Innovation also appears to be closely related to the environment and requires new ideas to be developed and transformed into products, services or processes in the company. The context of ongoing and constant changes in which industrial companies operate demands of them a permanent ability to make organizational changes.

The goal of any organization is to build profit and provide best practice or service to their customers and before that the organization must be ensure that their pool of employees must have the capabilities that are required to fulfill the customer needs, Creativity is one of those requirements. Creative employees is competitive advantage in today's knowledge economy for the organization and if any organization have the creative employees so that they have to sustain them by giving them appropriate workload according to their capabilities and also ensure that they will manage that workload. We tried to cover the gap with respect to Pakistan's industries namely, Information technology, Educational and Advertisement agencies that operate mainly in Pakistan. By combining an approach of several papers such as (Teresa M. Amabile et al., 1996; Jothi \& Hin, 2015; Lin \& Liu, 2012) in a holistic idea to identify the antecedents of creativity that lies within the Pakistani industry. These factors include Leaders Behavior, Perceived Organizational Support, Social Support, Resources, Workload, Person job fit, Freedom, and Challenging work. Perceived Organizational Support was further classified into Supervisory encouragement, Organizational impediments, and Work group supports. We also categorize creativity into Quantity and Quality. However we also suggested a mediating role of Job Stressors that include Challenge and Hindrance stressors, and work pressures in environment and creativity. Meanwhile our results have shown that; only one variable of job stressors was significantly affected by Leader behavior, POS and challenging work. While we could not meet our expectation that there is an effect of creativity on innovation and motivation. We presume that our research will fulfil the gap underlying with respect Pakistan 3 sectors of IT, Education and Advertising Agencies and 
will help the Scholars, Academicians Managers and Organization to focus on the right path as suggested by this study.

We propose that this study was confined and is applicable in Pakistan and with 3 respective sectors and responses were limited to best of time and availability, however we suggest that results can be different if the sample and population differs. Therefore we presume that if the study is to be conducted in several other private sectors, the results can be satisfying as well as we recommend public sector for the future research and study over the same tenets of this study.

\section{References}

Adler, P. S., \& Chen, C. X. (2011). Combining creativity and control: Understanding individual motivation in large-scale collaborative creativity. Accounting, organizations and society, 36(2), 63-85. https://doi.org/10.1016/j.aos.2011.02.002

Ahearne, M., Rapp, A., Hughes, D. E., \& Jindal, R. (2010). Managing sales force product perceptions and control systems in the success of new product introductions. Journal of Marketing Research. https://doi.org/10.1509/jmkr.47.4.764

Altaf, A., \& Awan, M. A. (2011). Moderating Affect of Workplace Spirituality on the Relationship of Job Overload and Job Satisfaction. Journal of Business Ethics. https://doi.org/10.1007/s10551-011-0891-0

Amabile, T. M. (1998). How to kill creativity. Harvard Business Review.

Amabile, T. M. (1979). Effects of external evaluation on artistic creativity. Journal of Personality and Social Psychology, 37. https://doi.org/10.1037/0022-3514.37.2.221

Amabile, T. M., Goldfarb, P., \& Brackfield, S. 1990. Social influences on creativity: Evaluation, coaction, and surveillance. Creativity Research Journal, 3, 6-21. https://doi.org/10.1080/ 10400419009534330

Amabile, T. M., Hennessey, B. A., \& Grossman, B. S. (1986) Social influences on creativity: The effects of contracted-for reward. Journal of Personality and Social Psychology, 50, 14-23. https://doi.org/10.1037/0022-3514.50.1.14

Amabile, T. M. (1988). A model of creativity and innovation in organization. in B.M. Staw, \& L.L. Cummings (Eds), Research in Organizational Behavior (Vol. 10, pp. 123-67) JAI Press, Greenwich, CT.

Amabile, T. M. (1996), Creativity in Context: Update to the Social Psychology of Creativity, Westview Press, Boulder, CO.

Amabile, T. M., Burnside, R. M., \& Gryskiewicz, S. (1999). User's Manual for Assessing the Climate for Creativity: A Survey from the Center for Creativity Leadership, Center for Creativity Leadership.

Amabile, Teresa M. (1988). A Model of Creativity and Innovation in Organizations. In Research in Organizational Behavior. https://doi.org/Article 


\section{$\triangle$ Macrothink}

Amabile, Teresa M., Conti, R., Coon, H., Lazenby, J., \& Herron, M. (1996). Assessing the work environment for creativity. Academy of Management Journal, 39(5), 1154-1184. https://doi.org/10.2307/256995

Andrews, F. M., \& Farris, G. F. (1972). Time pressure and performance of scientists and engineers: A five-year panel study. Organizational Behavior and Human Performance, 8, 185-200. https://doi.org/10.1016/0030-5073(72)90045-1

Andrews, J., \& Smith, D. C. (1996). In search of the marketing imagination: Factors affecting the creativity of marketing programs for mature products. Journal of Marketing Research, 33(2), 174-187. https://doi.org/10.1177/002224379603300205

Austin, D. R. (2013). Measuring and managing performance in organizations.

Avery, D. R., Tonidandel, S., Volpone, S. D., \& Raghuram, A. (2010). Overworked in America?: How work hours, immigrant status, and interpersonal justice affect perceived work overload. Journal of Managerial Psychology. https://doi.org/10.1108/02683941011019348

Babcock-Roberson, M. E., \& Strickland, O. J. (2010). The relationship between charismatic leadership, work engagement, and organizational citizenship behaviors. Journal of Psychology: Interdisciplinary and Applied. https://doi.org/10.1080/00223981003648336

Baer, M. (2012). Putting creativity to work: The implementation of creative ideas in organizations. Academy of Management Journal, 55(5), 1102-1119. https://doi.org/10.5465/ amj.2009.0470

Baer, M., \& Oldham, G. R. (2006). The curvilinear relation between experienced creative time pressure and creativity: Moderating effects of openness to experience and support for creativity. Journal of Applied Psychology, 91(4), 963-970. https://doi.org/10.1037/0021-9010.91.4.963

Bakker, A. B., \& Xanthopoulou, D. (2013). Creativity and charisma among female leaders: The role of resources and work engagement. International Journal of Human Resource Management, 24(14), 2760-2779. https://doi.org/10.1080/09585192.2012.751438

Bakker, A. B., Evangelia, D., \& Verbeke, W. (2004). Using the job demands-resources model to predict burnout and performance. Human Resource Management, 43(1), 83-104. https://doi.org/10.1002/hrm.20004

Bammens, Y., Notelaers, G., \& van Gils, A. (2013). Employees As a Source of Innovation: the Role of Perceived Organizational Support in Family Firms. Academy of Management Annual Meeting Proceedings, 89-94. https://doi.org/10.5465/ambpp.2013.29

Barron, R., Kenny, D. (1986). he moderator-mediator distinction in social psychology: Conceptual, strategic and statistical considerations. Journal of Personality and Social Psychology. https://doi.org/10.1037/0022-3514.51.6.1173

Boswell, W. R., Olson-Buchanan, J. B., \& LePine, M. A. (2004). Relations between stress and work outcomes: The role of felt challenge, job control, and psychological strain. Journal of Vocational Behavior, 64, 165-181. https://doi.org/10.1016/S0001-8791(03)00049-6 
Bowling, N. A., \& Kirkendall, C. (2012). Workload: A Review of Causes, Consequences, and Potential Interventions. In Contemporary Occupational Health Psychology: Global Perspectives on Research and Practice. https://doi.org/10.1002/9781119942849.ch13

Bowling, N. A., Alarcon, G. M., Bragg, C. B., \& Hartman, M. J. (2015). A meta-analytic examination of the potential correlates and consequences of workload. Work and Stress. https://doi.org/10.1080/02678373.2015.1033037

Bunce, D., \& West, M. (1994). Changing work environments: Innovating coping responses to occupation stress. Work and Stress, 8, 319-331. https://doi.org/10.1080/02678379408256539

Byron, K. (2005). A meta-analytic review of work-family conflict and its antecedents. Journal of Vocational Behavior, 67(2), 169-198. https://doi.org/10.1016/j.jvb.2004.08.009

Byron, K., Khazanchi, S., \& Nazarian, D. (2010). The relationship between stressors and creativity: A meta-analysis examining competing theoretical models. Journal of Applied Psychology, 95, 201-212. https://doi.org/10.1037/a0017868

Cai, W., Lysova, E. I., Khapova, S. N., \& Bossink, B. A. G. (2019). Does Entrepreneurial Leadership Foster Creativity Among Employees and Teams? The Mediating Role of Creative Efficacy Beliefs. Journal of Business and Psychology, 34(2), 203-217. https://doi.org/10.1007/s10869-018-9536-y

Cannon-Bowers, J. A., \& Salas, E. (1997). A framework for developing team performance measures in training. In Team performance assessment and measurement: Theory, methods, and applications (pp. 45-62).

Carmeli, A., Dutton, J. E., \& Hardin, A. E. (2015). Respect as an engine for new ideas: Linking respectful engagement, relational information processing and creativity among employees and teams. Human Relations, 68(6), 1021-1047. https://doi.org/10.1177/0018726714550256

Cavanaugh, M. A., Boswell, W. R., Roehling, M. V., \& Boudreau, J. W. (2000). An empirical examination of self-reported work stress among U.S. managers. Journal of Applied Psychology, 85(1), 65-74. https://doi.org/10.1037/0021-9010.85.1.65

Chang, S., Gong, Y., \& Shum, C. (2011). Promoting innovation in hospitality companies through human resource management practices. International Journal of Hospitality Management. https://doi.org/10.1016/j.ijhm.2011.01.001

Chen, X. P., Eberly, M. B., Chiang, T. J., Farh, J. L., \& Cheng, B. S. (2014). Affective Trust in Chinese Leaders: Linking Paternalistic Leadership to Employee Performance. Journal of Management. https://doi.org/10.1177/0149206311410604

Chin, W. W. (1998). Commentary Issues and Opinion on Structural Equation Modeling Clear Reporting. Modern Methods for Business Research Methodology for Business and Management.

Coelho, F., \& Augusto, M. (2010). Job characteristics and the creativity of frontline service employees. Journal of Service Research, 13(4), 426-438. 
https://doi.org/10.1177/1094670510369379

Collins, J., \& Cooke, D. K. (2013). Creative role models, personality and performance. Journal of Management Development, 32(4), 336-350. https://doi.org/10.1108/02621711311326347

Cowen, E. L. (1952). The influence of varying degrees of psychological stress on problem-solving rigidity. Journal of Abnormal and Social Psychology, 47, 420-424. https://doi.org/10.1037/h0061799

Cowie, H., Naylor, P., Rivers, I., Smith, P. K., \& Pereira, B. (2002). Measuring workplace bullying. Aggression and Violent Behavior, 7(1), 33-51. https://doi.org/10.1016/S1359 $-1789(00) 00034-3$

Crawford, E. R., LePine, J. A., \& Rich, B. L. (2010). Linking job demands and resources to employee engagement and burnout: A theoretical extension and meta-analytic test. Journal of Applied Psychology, 95, 834-848. https://doi.org/10.1037/a0019364

Darmon, R., \& Martin, X. (2011). A new conceptual framework of sales force control systems. Journal of Personal Selling and Sales Management. https://doi.org/10.2753/PSS08853134310307

Davis, G. A., Rimm, S. B., \& Siegle, D. (2010). Education of the gifted and talented (6th ed) (6th ed.).

De Jonge, J., \& Dormann, C. (2003). The DISC model: Demand-induced strain compensation mechanisms in job stress. Occupational Stress in the Service Professions, May 2014, 43-74. https://doi.org/10.1201/9780203422809.ch2

Deci, E. L., \& Ryan, R. M. 1985. Intrinsic motivation and self-determination in human behavior. New York: Plenum. https://doi.org/10.1007/978-1-4899-2271-7

Dul, J., \& Ceylan, C. (2010). Work environments for employee creativity. Ergonomics, 0139, 1-25. https://doi.org/10.1080/00140139.2010.542833

Dul, J., Ceylan, C., \& Jaspers, F. (2011). Knowledge workers' creativity and the role of the physical work environment. Human resource management, 50(6), 715-734. https://doi.org/10.1002/hrm.20454

Ebrahimi, P., Rezvani Chamanzamin, M., Roohbakhsh, N., \& Shaygan, J. (2017). Transformational and transactional leadership: Which one is more effective in the education of employees' creativity? Considering the moderating role of learning orientation and leader gender. International Journal of Organizational Leadership, 6(1), 137-156. https://doi.org/10.33844/ijol.2017.60196

Edwards, J. R. (1991). Person-job fit: A conceptual integration, literature review, and methodological critique. John Wiley \& Sons.

EG Carmines, R. Z. (1979). Reliability and validity assessment. https://doi.org/10.4135/ 9781412985642 


\section{Macrothink}

Human Resource Research

ISSN 1948-5441

2020, Vol. 4, No. 1

Eisenberger, R., Malone, G. P., \& Presson, W. D. (2016). Optimizing Perceived Organizational Support to Enhance Employee Engagement. Society for Human Resource Management, 1-22. http://www.siop.org/SIOP-SHRM/SHRM-SIOP POS.pdf

Ekvall, G. (1996). Organizational climate for creativity and innovation. European Journal of Work and Organizational Psychology, 5(1), 105-23. https://doi.org/10.1080/1359432 9608414845

Ekvall, G., \& Ryhammar, L. (1999). The creative climate: its determinants and effects at a Swedish university. Creativity Research Journal, 12(4), 303-10. https://doi.org/10.1207/s1532 6934crj1204_8

F., M. R., \& Blau, S. (2007). Workload factors impacting managers. Journal of Management Development, Unit 07, 1-5.

Farh, J. L., Hackett, R. D., \& Liang, J. (2007). Individual-level cultural values as moderators of perceived organizational support-employee outcome relationships in China: Comparing the effects of power distance and traditionality. Academy of Management Journal. https://doi.org/10.5465/amj.2007.25530866

Feifei, R., \& Jinghuan, Z. (2015). Job Stressors, Organizational Innovation Climate, and Employees' Innovative Behavior. Creativity Research Journal, 27(1), 16-23. https://doi.org/10.1080/10400419.2015.992659

Ford, C. M. (1996). A theory of individual creative action in multiple social domains. Academy of Management Review, 21(4), 1112-42. https://doi.org/10.5465/amr.1996.9704071865

Fornell, C., \& Larcker, D. F. (1981). Evaluating Structural Equation Models with Unobservable Variables and Measurement Error. Journal of Marketing Research. https://doi.org/10.2307/3151312

Füller, J., Hutter, K., \& Faullant, R. (2011). Why co-creation experience matters? Creative experience and its impact on the quantity and quality of creative contributions. $R$ and $D$ Management. https://doi.org/10.1111/j.1467-9310.2011.00640.x

George, J. M. (2007). 9 Creativity in Organizations. The Academy of Management Annals. https://doi.org/10.1080/078559814

George, J. M., \& Zhou, J. (2002). Understanding when bad moods foster creativity and good ones don't: The role of context and clarity of feelings. Journal of Applied Psychology, 87(4), 687-697. https://doi.org/10.1037//0021-9010.87.4.687

Gilboa, S., Shirom, A., Fried, Y., \& Cooper, C. (2008). A meta-analysis of work demand stressors and job performance: Examining main and moderating effects. Personnel Psychology. https://doi.org/10.1111/j.1744-6570.2008.00113.x

Glaser, R. (2015). Stress-Induced Immunomodulation.

Glazer, S., \& Beehr, T. A. (2005). Consistency of implications of three role Stressors across four countries. Journal of Organizational Behavior, 26(5), 467-487. 
https://doi.org/10.1002/job.326

Gong, Y., Huang, J. C., \& Farh, J. L. (2009). Employee learning orientation, transformational leadership, and employee creativity: The mediating role of employee creative self-efficacy. Academy of Management Journal. https://doi.org/10.5465/AMJ.2009.43670890

Goodsir, W., Neill, L., Williamson, D., \& Brown, A. (2014). Journalistic integrity or arbiter of taste? the case study of restaurant critic Peter Calder. Journal of Hospitality and Tourism Management. https://doi.org/10.1016/j.jhtm.2014.09.001

Gu, Q., Tang, T. L. P., \& Jiang, W. (2013). Does Moral Leadership Enhance Employee Creativity? Employee Identification with Leader and Leader-Member Exchange (LMX) in the Chinese Context. Journal of Business Ethics, 126(3), 513-529. https://doi.org/10.1007/s10551-013-1967-9

Haar, J. M. (2006). Challenge and hindrance stressors in New Zealand: Exploring social exchange theory outcomes. International Journal of Human Resource Management. https://doi.org/10.1080/09585190601000147

Hackman, J. R., \& Oldham, G. R. (1976). Motivation through the design of work: test of a theory. Organizational Behavior and Human Performance, 16(2), 250-279. https://doi.org/10.1016/0030-5073(76)90016-7

Harvey, S., Kelloway, E. K., \& Duncan-Leiper, L. (2003). Trust in Management as a Buffer of the Relationships Between Overload and Strain. Journal of Occupational Health Psychology, 8(4), 306-315. https://doi.org/10.1037/1076-8998.8.4.306

Hernández-Espallardo, M., Rodríguez-Orejuela, A., \& Sánchez-Pérez, M. (2010). Inter-organizational governance, learning and performance in supply chains. Supply Chain Management. https://doi.org/10.1108/13598541011028714

Hernández-Torrano, D., \& Ibrayeva, L. (2020). Creativity and education: A bibliometric mapping of the research literature (1975-2019). Thinking Skills and Creativity, 35(December 2019), 100625. https://doi.org/10.1016/j.tsc.2019.100625

Hon, A. H. Y. (2011). Enhancing employee creativity in the Chinese context: The mediating role of employee self-concordance. International Journal of Hospitality Management. https://doi.org/10.1016/j.ijhm.2010.06.002

Hon, A. H. Y., \& Kim, T.-Y. (2007). Work Overload and Employee Creativity: The Roles of Goal Commitment, Task Feedback from Supervisor, and Reward for Competence. Current Topics in Management, January 2007, 193-211. https://doi.org/10.4324/9780203794012-11

Hur, W.-M., Moon, T., \& Jun, J.-K. (2016). The effect of workplace incivility on service employee creativity: the mediating role of. Journal of Services Marketing, 30(3), 302-315. https://doi.org/10.1108/JSM-10-2014-0342

Isaksen, S. G., Lauer, K. J., \& Ekvall, G. (1999). Situational Outlook Questionnaire: a measure of the climate for creativity and change. Psychological Reports, 85(2), 665-74. 
https://doi.org/10.2466/PR0.85.6.665-674

Janssen, O. (2000). Job demands, perceptions of effort-reward fairness and innovative work behaviour. Journal of Occupational and Organizational Psychology, 73(3), 287-302. https://doi.org/10.1348/096317900167038

Janssen, O., Van de Vliert, E., \& West, M. (2004). The bright and dark sides of individual and group innovation: A special issue introduction. Journal of Organizational Behavior, 25, 129-145. https://doi.org/10.1002/job.242

Jex, S. M. (1998). Stress and job performance: Theory, research, and implications for managerial practice. Thousand Oaks, CA: Sage.

Jex, S. M., Bliese, P. D., Buzzell, S., \& Primeau, J. (2001). The Impact of Self-Efficacy on Stressor-Strain Relations: Coping Style as an Explanatory Mechanism. 86(3), 401-409. https://doi.org/10.1037/0021-9010.86.3.401

Jothi, J. A. J., \& Hin, C. W. (2015). Private higher education institutions in Malaysia. A Global Perspective on Private Higher Education, 4(06), 131-155. https://doi.org/10.1016/B978 $-0-08-100872-0.00008-2$

Khazanchi, S., \& Masterson, S. S. (2011). Who and what is fair matters: A multi-foci social exchange model of creativity. Journal of Organizational Behavior, 32(1), 86-106. https://doi.org/10.1002/job.682

Kim, T. Y., Hon, A. H. Y., \& Lee, D. R. (2010). Proactive personality and employee creativity: The effects of job creativity requirement and supervisor support for creativity. Creativity Research Journal, 22(1), 37-45. https://doi.org/10.1080/10400410903579536

Kristof, A. L. (1996). Person-organization fit: An integrative review of its conceptualizations, measurement, and implications. Personnel Psychology, 49, 1-49. https://doi.org/10.1111/ j.1744-6570.1996.tb01790.x

Kristof, A., Zimmerman, R., \& Johnson, E. (2005). Consequences of individuals' fit at work: Person-organization, person-group, and person-supervisor fit. Personnel Psychology, 58, 281-342. https://doi.org/10.1111/j.1744-6570.2005.00672.x

Kumar, M. N. (2017). DESIGN THINKING FOR INNOVATION: HOW CREATIVITY CAN SOLVE OUR BIGGEST PROBLEMS. Proceedings of the Academy of Management Information and Decision Sciences, 21.

Landau, L. (1937). The Link between Job Satisfaction and Organizational Commitment Differences between Public and Private sector employees. Zhurnal Eksperimental'noi $i$ Teoreticheskoi Fiziki, 1-37.

Lauver, K. J., \& Kristof-Brown, A. (2001). Distinguishing between employees' perceptions of person-job and person-organization fit. Journal of Vocational Behavior, 59(3), 454-470. https://doi.org/10.1006/jvbe.2001.1807

Lazarus, R. S. (1966). Psychological stress and the coping process. New York, NY: 
McGraw-Hill.

Lee, Y. W., Han, S. Il, Joo, S. J., Jang, S., Na, C., Okamoto, S., Arimoto, N., Lim, D., Kim, H. S., \& Yoon, S. J. (2013). Two distinct red giant branch populations in the globular cluster NGC 2419 as tracers of a merger event in the milky way. Astrophysical Journal Letters, 778(1), 1-4. https://doi.org/10.1088/2041-8205/778/1/L13

LePine, J. A., Podsakoff, N. P., \& LePine, M. A. (2005). A metaanalytic test of the challenge stressor-hindrance stressor framework: An explanation for inconsistent relationships among stressors and performance. Academy of Management Journal, 48, 764-775. https://doi.org/10.5465/amj.2005.18803921

Lin, C. Y. Y., \& Liu, F. C. (2012). A cross-level analysis of organizational creativity climate and perceived innovation: The mediating effect of work motivation. European Journal of Innovation Management, 15(1), 55-76. https://doi.org/10.1108/14601061211192834

Liu, D., Chen, X. P., \& Yao, X. (2011). From autonomy to creativity: A multilevel investigation of the mediating role of harmonious passion. Journal of Applied Psychology, 96(2), 294-309. https://doi.org/10.1037/a0021294

Lynch, P. D., Eisenberger, R., \& Armeli, S. (1999). Perceived organizational support: Inferior versus superior performance by wary employees. Journal of Applied Psychology. https://doi.org/10.1037/0021-9010.84.4.467

Martı'n, P., Salanova, M., \& Peiro', J. M. (2007). Job demands, job resources and individual innovation at work: Going beyond Karasek's model? Psicothema, 19, 621-626.

Mayer, K., \& Solga, H. (2008). Skill formation: Interdsiciplinary and cross National Perspectives. https://doi.org/10.1017/CBO9780511499593

McLean, L. D. (2005). Organizational Culture's Influence on Creativity and Innovation: A Review of the Literature and Implications for Human Resource Development. Advances in Developing Human Resources, 7(2), 226-246. https://doi.org/10.1177/1523422305274528

Mehta, R., \& Zhu, M. (2016). Creating when you have less: The impact of resource scarcity on product use creativity. Journal of Consumer Research, 42(5), 767-782. https://doi.org/10. 1093/jcr/ucv051

Mitchell, T. R. (1982). Motivation: New Directions for Theory, Research, and Practice. Academy of Management Review. https://doi.org/10.5465/amr.1982.4285467

Moeini, B., Shafii, F., Hidarnia, A., Babaii, G. R., Birashk, B., \& Allahverdipour, H. (2008). Perceived stress, self-efficacy and its relations to psychological well-being status in Iranian male high school students. Social Behavior and Personality: An International Journal, 36(2), 257-266. https://doi.org/10.2224/sbp.2008.36.2.257

Mumford, M. D., Scott, G. M., Gaddis, B., \& Strange, J. M. (2002). Leading creative people : Orchestrating expertise and relationships. The Leadership Quarterly, 13(6), 705-750. https://doi.org/http://dx.doi.org/10.1016/S1048-9843(02)00158-3 


\section{Macrothink}

Human Resource Research

ISSN 1948-5441 2020, Vol. 4, No. 1

Ngo, L. V., Nguyen, N. P., Lee, J., \& Andonopoulos, V. (2020). Mindfulness and job performance: Does creativity matter? Australasian Marketing Journal, xxxx. https://doi.org/10.1016/j.ausmj.2019.12.003

O’Reilly, C. A., \& Tushman, M. L. (1997). Using culture for strategic advantage: promoting innovation through social control. Managing Strategic Innovation and Change.

Ohly, S. (2018). Promoting Creativity at Work - Implications for Scientific Creativity. European Review, 26(S1), S91-S99. https://doi.org/10.1017/S1062798717000576

Omisore, B. O. (2014). Supervision - Essential To Productivity. Global Journal of Commerce \& Management Perpective, 3(2), 104-108.

Parnes, S. J. 1964. Research on developing creative behavior. In C. W. Taylor (Ed.), Widening horizons in creativity: 145-169. New York: Wiley

Parnes, S. J., \& Meadow, A. 1959. Effects of brainstorming instructions on creative problem solving of trained and untrained subjects. Journal of Educational Psychology, 50, 171-176. https://doi.org/10.1037/h0047223

Parnes, S. J., \& Noller, R. B. 1972. Applied creativity: The creative studies project-Part II: Results of the two-year program. Journal of Creative Behavior, 6, 164-186. https://doi.org/10.1002/j.2162-6057.1972.tb00927.x

Pearsall, M. J., Ellis, A. P. J., \& Stein, J. H. (2009). Coping with challenge and hindrance stressors in teams: Behavioral, cognitive, and affective outcomes. Organizational Behavior and Human Decision Processes. https://doi.org/10.1016/j.obhdp.2009.02.002

Podsakoff, N. P., Lepine, J. A., \& Lepine, M. A. (2007). Differential challenge stressor-hindrance stressor relationships with job attitudes, turnover intentions, turnover, and withdrawal behavior: A meta-analysis. Journal of Applied Psychology. https://doi.org/10.1037/0021-9010.92.2.438

Rabbani, S., \& Sarmad, M. (2018). Creative Self-Efficacy as the Mediator between Climate for Creativity and Creativity: Empirical Evidence from R\&D of IT Sector of Pakistan. Abasyn University Journal of Social Sciences. https://doi.org/10.34091/AJSS.12.1.10

Rahman, S. (2017). www.econstor.eu.

Rahman, Z. (2016). Sharing Efforts and Organizational Context. https://doi.org/10.5465/ ambpp.2016.39

Rhoades, L., \& Eisenberger, R. (2002). Perceived organizational support: a review of the literature. Journal of applied psychology, 87(4), 698. https://doi.org/10.1037/00219010.87.4.698

Ro, H., \& Chen, P. J. (2011). Empowerment in hospitality organizations: Customer orientation and organizational support. International Journal of Hospitality Management. https://doi.org/10.1016/j.ijhm.2010.09.003 
Ryan, R., \& Deci, E. (2000). Self-determination theory and the facilitation of intrinsic motivation. American Psychologist, 55(1), 68-78. https://doi.org/10.1037/0003-066X.55.1.68

Ryhammar, L., \& Smith, G. J. W. (1999). Creative and other personality functions as defined by percept-genetic techniques and their relation to organizational conditions. Creativity Research Journal, 12, 277-286.

Scott, S. G., \& Bruce, R. A. (1994). Determinants of Innovative Behavior: A Path Model of Individual Innovation in the Workplace. Academy of Management Journal. https://doi.org/10.5465/256701

Scott, S. G., \& Bruce, R. A. (1994, October). Creating innovative behavior among R\&D professionals: the moderating effect of leadership on the relationship between problem-solving style and innovation. In Proceedings of 1994 IEEE International Engineering Management Conference-IEMC'94 (pp. 48-55). IEEE.

Shalley, C. E. (1995). Effects of Coaction, Expected Evaluation, And Goal Setting On Creativity And Productivity. Academy of Management Journal. https://doi.org/10.5465/ 256689

Shalley, C. E., \& Gilson, L. L. (2004). What leaders need to know: A review of social and contextual factors that can foster or hinder creativity. Leadership Quarterly, 15(1), 33-53. https://doi.org/10.1016/j.leaqua.2003.12.004

Shao, Y., Nijstad, B. A., \& Täuber, S. (2019). Creativity under workload pressure and integrative complexity: The double-edged sword of paradoxical leadership. Organizational Behavior and Human Decision Processes, 155(January), 7-19. https://doi.org/10.1016/j.obhdp.2019.01.008

Sharma, P. N., \& Kirkman, B. L. (2015). Leveraging Leaders: A Literature Review and Future Lines of Inquiry for Empowering Leadership Research. Group and Organization Management. https://doi.org/10.1177/1059601115574906

Shikieri, A. B. El, \& Musa, H. A. (2012). Factors Associated with Occupational Stress and Their Effects on Organizational Performance in a Sudanese University. Creative Education. https://doi.org/10.4236/ce.2012.31022

Shore, L. M., \& Shore, T. H. (1995). Perceived organizational support and organizational justice. Organizational politics, justice, and support: Managing the social climate of the workplace, 149, 164.

Shrout, P. E., \& Bolger, N. (2002). Mediation in experimental and nonexperimental studies: New procedures and recommendations. Psychological Methods. https://doi.org/10.1037/1082-989X.7.4.422

Smith, W. K., Lewis, M. W., \& Tushman, M. L. (2016). Both/and leadership. Harvard Business Review, 94(5), 62-70.

Smith, W., \& Lewis, M. (2011). Toward a theory of paradox: A dynamic equilibrium model of 
organizing. Academy of Management Review, 36(2), 381-403. https://doi.org/10.5465/ AMR.2011.59330958

Spelthann, V., \& Haunschild, A. (2011). Organizational Creativity in Heterarchies: The Case of VFX Production. Creativity and Innovation Management. https://doi.org/10.1111/j.1467-8691. 2011.00598.x

Stokols, D., Clitheroe, C., \& Zmuidzinas, M. (2002). Qualities of work environments that promote perceived support for creativity. Creativity Research Journal, 14, 137-147. https://doi.org/10.1207/S15326934CRJ1402_1

Syrek, C. J., Apostel, E., \& Antoni, C. H. (2013). Stress in highly demanding it jobs: Transformational leadership moderates the impact of time pressure on exhaustion and work-life balance. Journal of Occupational Health Psychology. https://doi.org/10.1037/ a0033085

Taggar, S. (2002). Individual creativity and group ability to utilize individual creative resources: A multilevel model. Academy of management Journal, 45(2), 315-330. https://doi.org/10.2307/3069349

Tang, Y.-T., \& Chang, C.-H. (2010). Impact of Role Ambiguity and Role Conflict on Employee Creativity. African Journal of Business Management, 4(6), 869-881.

Tierney, P., Farmer, S. M., \& Graen, G. B. (1999). An examination of leadership and employee creativity: The relevance of traits and relationships. Personnel Psychology, 52(3), 591-620. https://doi.org/10.1111/j.1744-6570.1999.tb00173.x

Tsai, C. T., \& Kao, C. F. (2004). The relationships among motivation orientations, climate for organization innovation, and employee innovative behavior: a test of Amabile's motivational synergy model. Journal of Management, 21(5), 571-2.

Tunc, T. E. (2012). Less sugar, more warships: Food as American propaganda in the first world war. In War in History. https://doi.org/10.1177/0968344511433158

Usman, M., \& Xiao, S. (2017). Creativity of Employees in Local Domestic Manufacturing Industry : Evidence from Pakistan. 2017 4th International Conference on Industrial Economics System and Industrial Security Engineering (IEIS). IEEE. https://doi.org/10.1109/IEIS. 2017.8078603

van Knippenberg, D., \& Sitkin, S. B. (2013). A critical assessment of charismatic - transformational leadership research: Back to the drawing board? Academy of Management Annals. https://doi.org/10.1080/19416520.2013.759433

Version, A. (2004). Durham Research Online. Journal of Business Ethics, 44(April), 0-103. https://doi.org/10.1063/1.2756072

Vinarski-Peretz, H., Binyamin, G., \& Carmeli, A. (2011). Subjective relational experiences and employee innovative behaviors in the workplace. Journal of vocational behavior, $78(2)$, 290-304. https://doi.org/10.1016/j.jvb.2010.09.005 
Voydanoff, P. (2005). Work demands and work-to-family and family-to-work conflict: Direct and indirect relationships. Journal of Family Issues, 26(6), 707-726. https://doi.org/10.1177/ 0192513 X05277516

Waldman, D. A., \& Bowen, D. E. (2016). Learning to be a paradox-savvy leader. Academy of Management Perspectives, 30(3), 316-327. https://doi.org/10.5465/amp.2015.0070

West, M. A. (2002). Sparkling fountains or stagnant ponds: An integrative model of creativity and innovation implementation in work groups. Applied Psychology: An International Review, 51, 355-387. https://doi.org/10.1111/1464-0597.00951

Wong, S., \& Pang, L. (2003). Motivators to creativity in the hotel industry - Perspectives of managers and supervisors. Tourism Management. https://doi.org/10.1016/S0261-5177 (03)00004-9

WOODMAN, R. W., \& SCHOENFELDT, L. F. (1990). An Interactionist Model of Creative Behavior. The Journal of Creative Behavior. https://doi.org/10.1002/j.2162-6057. 1990.tb00525.x

Woodman, R. W., Sawyer, J. E., \& Griffin, R. W. (1993). Toward a Theory of Organizational Creativity. Academy of Management Review. https://doi.org/10.5465/amr.1993.3997517

Yeh, S. S., \& Huan, T. C. (2017). Assessing the impact of work environment factors on employee creative performance of fine-dining restaurants. Tourism Management, 58, 119-131. https://doi.org/10.1016/j.tourman.2016.10.006

Yeh-Yun Lin, C., \& Yi-Ching Chen, M. (2007). Does innovation lead to performance? An empirical study of SMEs in Taiwan. Management Research News. https:/doi.org/ 10.1108/01409170710722955

Yong, K., Mannucci, P. V., \& Lander, M. W. (2020). Fostering creativity across countries: The moderating effect of cultural bundles on creativity. Organizational Behavior and Human Decision Processes, 157(February 2018), 1-45. https://doi.org/10.1016/j.obhdp.2019.12.004

Yu, C., \& Frenkel, S. J. (2012). Explaining task performance and creativity from perceived organizational support theory: Which mechanisms are more important? Journal of Organizational Behavior, J. Organiz. Behav, 34, 1165-1181. https://doi.org/10.1002/job.1844

Zacher, H., Robinson, A. J. A., \& Rosing, K. (2014). Ambidextrous leadership and employees' self-reported innovative performance: The role of exploration and exploitation behaviors. Journal of Creative Behavior, 50(1), 24-46. https://doi.org/10.1002/jocb.66

Zhang, A. Y., Tsui, A. S., \& Wang, D. X. (2011). Leadership behaviors and group creativity in Chinese organizations: The role of group processes. Leadership Quarterly, 22(5), 851-862. https://doi.org/10.1016/j.leaqua.2011.07.007

Zhang, L., Bu, Q., \& Wee, S. (2018). International Journal of Stress Management ${ }^{\circledR}$. International Journal of Stress Management. Advance Online Publication. https://doi.org/10.1037/str0000112 


\section{Macrothink}

Human Resource Research

ISSN 1948-5441 2020, Vol. 4, No. 1

Zhang, Y., Waldman, D. A., Han, Y. L., \& Li, X. B. (2015). Paradoxical leader behaviors in people management: Antecedents and consequences. Academy of Management Journal, 58(2), 538-566. https://doi.org/10.5465/amj.2012.0995

Zhang, Yiwen, Lepine, J. A., Buckman, B. R., \& Wei, F. (2014). It's not fair"* or is it? The role of justice and leadership in explaining work stressor-job performance relationships. Academy of Management Journal. https://doi.org/10.5465/amj.2011.1110

Zhou, J., \& Shalley, C. E. (2008). Expanding the scope and impact of organizational creativity research. Hand Book of Organiztional Creativity.

Zhou, Q., Hirst, G., \& Shipton, H. (2012). Promoting Creativity at Work: The Role of Problem-Solving Demand. Applied Psychology, 61(1), 56-80. https://doi.org/10.1111/j.1464-0597.2011.00455.x

\section{Copyright Disclaimer}

Copyright for this article is retained by the author(s), with first publication rights granted to the journal.

This is an open-access article distributed under the terms and conditions of the Creative Commons Attribution license (http://creativecommons.org/licenses/by/3.0/). 